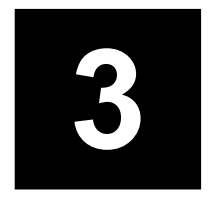

\title{
Wild Sorghums-Their Potential Use in Crop Improvement
}

\author{
Kamala Venkateswaran, ${ }^{1, *}$ Moses Muraya, ${ }^{2}$ SL Dwivedi ${ }^{3}$ and \\ HD Upadhyaya ${ }^{3}$
}

\begin{abstract}
Wild relatives of crops, sorghum being no exception, continue to play a key role in the development of high performing cultivars. Among the 22 species comprising this highly variable genus, only one, Sorghum bicolor, is commercially cultivated for food, feed and bioenergy production. The wild sorghums thus offer opportunities for further genetic enhancement of this crop. Profitable utilization of wild species however demands an inter-disciplinary, multi-pronged approach to increase the probability of achieving the desired genetic improvement. To this end, this chapter presents a review of the current knowledge on (1) biosystematic aspects such as botany, taxonomy and classification, (2) domestication and evolution, including centers of diversity, genetic diversity, chromosome homologies and species / phylogenetic relationships, (3) genetic resources, genepools and conservation perspectives including collections and preservation of germplasm, (4) utilization aspects including the specific potential of the wild species in crop improvement with reference to insect and disease resistance, yield, grain quality, ecological adaptation, allopatric resistance, and (5) strategies to maximize utilization of wild germplasm
\end{abstract}

\footnotetext{
${ }^{1}$ National Bureau of Plant Genetic Resources, Regional Station, Hyderabad 500030, Andhra Pradesh, India.

${ }^{2}$ Leibniz Institute of Plant Genetics and Crop Plant Research, Department of Molecular Genetics Corrensstrasse 3, 06466 Gatersleben, Germany.

${ }^{3}$ International Crops Institute for the Semi-Arid Tropics (ICRISAT) Patancheru PO 502324, Andhra Pradesh, India.

*Corresponding author: kgksvp@gmail.com
} 
resources including direct hybridization, reproductive barriers and their circumvention, chromosome and physiological manipulation, the gaps between hybridization and utilization and molecular interventions. Recent advancements in biotechnology, in particular, are expected to increase the efficiency and range of use of these wild sorghum species.

Keywords: Classification, conservation, distribution, genepools, phylogenetic relationships, utilization, wild relatives

\subsection{Introduction}

Sorghum [Sorghum bicolor (L.) Moench] is a significant cereal crop for the sustainable livelihood of the resource poor farmers of the semi-arid tropics. The grain is a major food in most of Africa, Asia and Central America while it is an important animal feed in the Americas and Australia. Sorghum crop residues and green plants also provide sources of animal feed, building materials and fuel particularly in dry land areas of the semi-arid tropics. Alternative uses include beer, alcohol and syrup production. Globally, the fifth most important cereal crop with an estimated world production of $54.2 \mathrm{~m}$ tons from a harvested area of about $35.4 \mathrm{~m}$ ha, sorghum is grown in 100 countries of Africa, Asia, Oceania and the Americas (FAO 2013). Predominantly grown under rainfed-marginal lands with low input farming systems, India, Nigeria, Mexico, the USA, Argentina and Ethiopia are the major producers.

Breeding efforts have been directed towards developing high yielding, photoperiod insensitive and abiotic and biotic stress resistant cultivars for adaptation to diverse agroclimatic conditions. The discovery of dwarfing genes in sorghum has led to the development of several short statured sorghum hybrids, which are responsive to high input agriculture. Nevertheless, sorghum productivity continues to be constrained by a wide range of pests and pathogens including over 40 diseases and more than 150 insect pests (Jotwani et al. 1980; Frederiksen and Duncan 1982). Estimated loss in grain yield due to sorghum downy mildew in unprotected over protected plots, ranged from 9.6 to $78.5 \%$ in different cultivars (Anahosur and Laxman 1991), and nearly $32 \%$ of the sorghum crop is reportedly lost due to insect pest infestation (Borad and Mittal 1983). Annual cereal losses due to parasitic weed, Striga, are estimated at US \$ 7 billion in Sub-Saharan Africa alone (AATF 2011). Despite the development of resistant varieties, levels of resistance in cultivated sorghum, particularly to insect pests, are low to moderate, and increased insect pressure combined with changing virulence patterns of the pest often cause breakdown of resistance (Sharma 
1993). This underscores the need to develop cultivars with broad-based resistance utilizing genes from diverse sources.

Wild species have frequently been used as sources of new genes in resistance breeding for abiotic and biotic stresses, agronomic and seed quality traits in various crops. Several examples are known where genes from wild relatives, both near and distant, have played a key role in salvaging a crop and preventing its failure as a commercial enterprise (Harlan 1984; Goodman et al. 1987; Dwivedi et al. 2008). These wild relatives are wild taxa that have an indirect use derived from their relatively close genetic relationship to a crop (Maxted et al. 2006). Most modern crop cultivars are known to contain some genes from a wild relative/progenitor, which are currently identified as a critical resource with a vital role in food and nutritional security and for environmental sustainability (Maxted et al. 1997b; Meilleur and Hodgkin 2004; Stolten et al. 2006).

Sorghum is a highly variable genus with about 22 species, of which, only one, S. bicolor, is commercially cultivated for food, feed and bioenergy production. The wild Sorghum species thus, represent a diverse source of germplasm with considerable potential to broaden the genetic potential of crop cultivars. As demand increases for more reliable food and feed sources from environments challenged by water shortage and high temperatures, sorghum will play a more prominent role due to its wider adaptation and diverse uses. Sorghum's relative drought and heat resistance may also increase its importance worldwide if the predicted effects of global warming come to pass (GCDT 2007). This chapter presents the potential of wild sorghum in improvement of the crop.

\subsection{Classification, Distribution and Botany}

Sorghum is classified under the family Poaceae (grass family), tribe Andropogoneae, subtribe Sorghastrae, and genus Sorghum Moench (Stapf 1917). Linnaeus (1753) first described in his "Species Plantarum" three species of cultivated sorghum: Holcus sorghum, Holcus saccaratus and Holcus tricolor. Moench (1794) distinguished the genus Sorghum from Holcus, and Person (1805) suggested the name Sorghum vulgare for Holcus sorghum (L.). In 1961, Clayton named cultivated sorghum as Sorghum bicolor (L.) Moench. Sorghum is a highly variable genus, comprising primarily 22 species (Fig. 3-1), grouped into five subgenera or sections: Eu sorghum, Chaetosorghum, Heterosorghum, Parasorghum and Stiposorghum (Garber 1950; Harlan and de Wet 1972; de Wet 1978; Lazarides et al. 1991).

Snowden $(1936,1955)$, gave the most comprehensive classification for section Eu sorghum. Two subsections viz., Arundinacea and Halepensia, were described, with former represented by 48 taxa: 28 cultivated species (series Sativa), 13 wild species, and seven representing hybrids (introgressed types) 


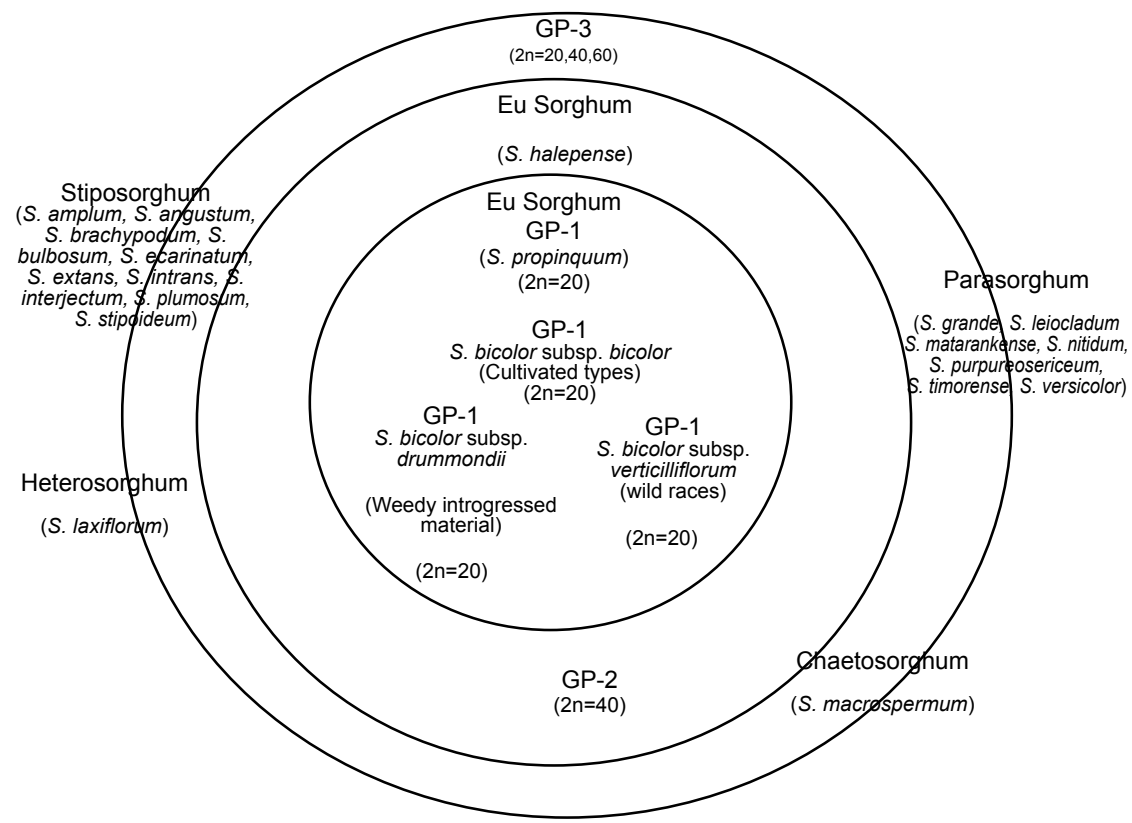

Figure 3-1 Sorghum genepools.

between wild and cultivated sorghums (series Spontanea); and the latter comprising four rhizomatous taxa: S. halepense, S. propinquum, S. miliaceum and $S$. controversum. All subsequent classifications of sorghum have been modifications of the Snowden system. Currently, the section Eu sorghum, has three species: two wild perennials, S. halapense (L.) Pers. and S. propinquum (Kunth) Hitchc., and the economically important and extensively variable annual, S. bicolor (L.) Moench (Table 3-1). The species S. bicolor (L.) Moench. $(2 n=20)$ includes all annual taxa recognized by Snowden $(1936,1955)$. It is subdivided into three subspecies: subsp. bicolor including an extremely diverse complex of domesticated taxa; subsp. verticilliflorum (Steud.) de Wet comb. nov. comprising of an ecologically and morphologically variable complex of wild taxa/progenitors of cultivated sorghum, which are widely distributed in Africa, and subsp. drummondii (Steud.) de Wet comb. nov including the weedy forms or stabilized derivatives of hybrids between cultivated sorghum and their close wild relatives. The three subspecies of S. bicolor together form an extremely variable crop-weed complex members which are fully interfertile.

All S. bicolor ssp. bicolor are annuals, with thick culms up to about $5 \mathrm{~m}$ tall, often branched and with tillers. Harlan and de Wet (1972), in a simplified classification, described five basic races in ssp. bicolor: bicolor, which is 
Table 3-1 Classification and distribution of Eu sorghum diversity (de Wet 1978; Wiersema and Dahlberg 2007).

\begin{tabular}{|l|l|l|l|l|l|}
\hline Genus & Section & Species & Subspecies & $\begin{array}{l}\text { Common } \\
\text { name }\end{array}$ & Distribution \\
\hline Sorghum & Sorghum & $\begin{array}{l}\text { S. bicolor } \\
\text { (L.) Moench } \\
(2 n=20)\end{array}$ & subsp. bicolor & $\begin{array}{l}\text { grain } \\
\text { sorghum }\end{array}$ & $\begin{array}{l}\text { Cultivated grain } \\
\text { sorghum }\end{array}$ \\
\hline & & $\begin{array}{l}\text { subsp. } \\
\text { Drummondii } \\
\text { (Steud.) de Wet } \\
\text { ex Davidse }\end{array}$ & Sudan grass & $\begin{array}{l}\text { Annual weedy } \\
\text { derivatives arising } \\
\text { from hybridization } \\
\text { of grain sorghum } \\
\text { (subsp. bicolor }) \\
\text { and its wild } \\
\text { relatives (subsp. } \\
\text { verticilliflorum) }\end{array}$ \\
\hline & & $\begin{array}{l}\text { subsp. } \\
\text { verticilliflorum } \\
\text { (Steud.) de Wet } \\
\text { ex Wiersema \& } \\
\text { J Dahlb., comb. } \\
\text { nov. }\end{array}$ & $\begin{array}{l}\text { common } \\
\text { wild } \\
\text { sorghum }\end{array}$ & $\begin{array}{l}\text { Annual wild } \\
\text { relatives, native } \\
\text { to Africa, } \\
\text { Madagascar; } \\
\text { introduced to India, } \\
\text { Australia, Americas }\end{array}$ \\
\hline & $\begin{array}{l}\text { S. halepense (L.) } \\
\text { Pers. (2n=40) }\end{array}$ & $\begin{array}{l}\text { S. propinquum } \\
\text { (Kunth) Hitchc. } \\
(2 n=20)\end{array}$ & $\begin{array}{l}\text { Southern Eurasia } \\
\text { east to India }\end{array}$ \\
\hline
\end{tabular}

widely distributed across the African Savannah and Asia; caudatum, found in Central Sudan and surrounding areas; guinea, which is grown in eastern and western Africa; durra, found primarily in Arabia and Asia Minor but also grown in India, Myanmar, Ethiopia and along the Nile Valley; and kafir, which is cultivated primarily in south eastern Africa. In addition they also recognized 10 intermediate races between all combinations of their hybrid derivatives so that a total of 15 races of cultivated sorghum are practically and easily distinguished based on mature spikelet/panicle morphology.

S. bicolor ssp. verticilliflorum (Steud.) Piper (earlier subsp. arundinaceum (Desv.) de Wet et Harlan) as described by de Wet et al. (1978) includes four botanical races/ecotypes: aethiopicum, arundinaceum, verticilliflorum and virgatum. These ecotypes overlap both morphologically and ecologically such that they do not deserve formal taxonomic status (Doggett 1988). This subsp. subsumes the 13 Snowdenian wild "species" (Snowden 1955). The widest distributed and most morphologically variable is race verticilliflorum of the African Savannah, introduced to tropical Australia, parts of India and the New World. It is characterized by large open inflorescences with spreading, but not pendulous branches, usually divided near the base. 
Race arundinaceum, distributed across moist tropical African forests, also has large open inflorescences, but with flexuous branches undivided near the base. Race aethiopicum, a desert grass across the African Sahel, has relatively small, contracted inflorescences with sub erect branches that are strongly divided, and large ovate lanceolate, densely tomentose sessile spikelets. Race virgatum of north eastern Africa, is distinguished from the others by its narrowly linear leaf blades that are rarely more than $2 \mathrm{~cm}$ wide; inflorescences are narrow with sub erect branches that may become somewhat flexuous at maturity.

Sorghum bicolor subsp. drummondii includes the seven weedy Snowdenian "species". This ssp. occurs as a weed in Africa wherever cultivated grain sorghum and their wild relatives are sympatric. These weeds occur across the range of sorghum cultivation in Africa and inflorescence morphology is determined by nature of introgression between the race of grain sorghum and race of subsp. verticilliflorum involved in hybridization.

Sorghum halepense $(2 n=40)$, an extensively variable rhizomatous perennial, is a native of southern Eurasia east to India, which collectively includes the three rhizomatous species recognized by Snowden (1955): S. halepense, S. miliaceum (Roxb.) Snowden and S. controversum (Steud.) Snowden. The common race/ecotype of $S$. halepense, which occupies the western range of the species has slender culms with relatively small, open, inflorescences and narrow leaf blades. In the eastern half of its range, this species, characterized by more robust plants, with culms up to $3 \mathrm{~m}$ tall, broader leaf blades and large inflorescences with panicles up to $55 \mathrm{~cm}$ is referred to as S. miliaceum. Some specimens from eastern and southern India referred to as $S$. controversum have densely hairy sessile spikelets rather than sparsely pubescent sessile spikelets at the base and above the middle as is characteristic of the more typical S. halepense. Hybrids and hybrid derivatives are aggressive colonizers, and have become widely distributed as weeds in Australia and the New World where the two parental species do not occur naturally. These weeds are commonly referred to as Johnson grass (S. halepense) in the USA and as S. almum Parodi in Argentina.

Sorghum propinquum $(2 n=20)$ is a robust tufted perennial with stout rhizomes that extends from Sri Lanka along the east coast of India to Myanmar and east to the islands of South East Asia. It is closely allied to S. halepense, differing from this species primarily in its smaller spikelets, and being a diploid rather than a tetraploid. This species crosses extensively with S. bicolor wherever they are sympatric to produce fully fertile hybrids, indicating cross-compatibility, thereby allowing the resultant hybrids to act as avenue for introgression. The absence of such barriers can explain why many intermediate types may be observed in nature. However, the geographical isolation and their natural distribution justify their recognition as separate species. 
Snowden (1936) used simple traits such as grain color, glume color, awns, and persistence of pedicellate spikelets. However, all of these characters vary widely within related forms to the point that they have little taxonomic value. Traits such as height, tillering, juiciness of stalk and day length response are useful for agronomic purposes, but also vary greatly among related forms and are not useful for classification purposes. The exhaustive and meticulous work of de Wet et al. (1970), Harlan and de Wet (1972) and de Wet (1978) on cytogenetics and classification resulted in the amalgamation and classification of all the variation (all Snowdenian "species" in "Arundinacea") into just three species within the section Eu sorghum: S. bicolor complex, Sorghum halepense and S. propinquum. Sorghum halepense is reproductively sufficiently isolated from both diploid S. bicolor and S. propinquum, to prevent the formation of intergrading populations with them; and S. propinquum is isolated geographically and largely ecologically from $S$. bicolor, or was until cultivated sorghum spread to South East Asia. They based their classification on spikelet morphology and grain characteristics and identified five main races of sorghum from the mature sessile spikelets alone. Their reasoning was that spikelet characters are considered to be the most stable, the least influenced by environment, and the most revealing with respect to relationships (Perumal et al. 2007). Classification of sorghum accessions in germplasm collection is challenging due to the relatively high level of introgression that has occurred during the evolution of sorghum (Doggett 1988).

Sections Chaetosorghum, Heterosorghum, Parasorghum and Stiposorghum contain 19 wild species native to Africa, Asia and Australia (Garber 1950; Lazarides et al. 1991). The monotypic sections Chaetosorghum and Heterosorghum are represented by S. macrospermum E.D. Garber and S. laxiflorum F.M. Bailey respectively. While the former is confined to the Port Darwin-Katherine region of the northern territory, Australia, the latter is restricted to northern Queensland, Australia, New Guinea, and the Philippine Islands. Parasorghum includes nine species with a range of distribution extending from south and eastern Africa in a discontinuous arc through India, southern and eastern coastal Asia and the East Indies to Australia along the east coast (Garber 1950). Three Parasorghum species are endemic to Australia (S.grande Lazarides, S. leiocladum (Hack.) C.E. Hubb., S. matarankense E.D. Garber and Snyder); S. timorense (Kunth) Buse is found in the Timor Islands and Australia; S. versicolor Andersson occurs in Africa; $S$. purpureo-sericeum (Hochst. Ex A. Rich) Asch \& Schweinf. in Asia and Africa and S. nitidum (Vahl) Pers. shows a distribution from Asia to Australia. These species range in ploidy from $2 n=10$ to $2 n=40$, with $S$. grande, $S$. nitidum and S. timorense showing varying ploidy within the species (Dillon et al. 2007). The section Stiposorghum comprises 10 species (S. amplum Lazarides, S. angustum S.T. Blake, S. brachypodum Lazarides, S. bulbosum Lazarides, S. ecarinatum 
Lazarides, S. extans Lazarides, S. interjectum Lazarides, S. intrans F. Muell. Ex Benth., S. plumosum (R.Br.) P. Beauv. and S. stipoideum (Ewart \& Jean White) C.A. Gardner \& C.E. Hubb (Garber, 1950, Lazarides et al. 1991). Most of these species are diploid with $2 n=10$, while $S$. interjectum has $2 n=30,40$ and S. plumosum has $2 n=10,20,30$ (Garber 1950; Lazarides et al. 1991). Members of Stiposorghum are confined to the northern territory of Australia and the lesser Sunda Islands. Characters of Australian sorghum are presented in Table 3-2. Lazarides and his associates (1991) who expanded on the earlier work of Garber (1950) accepted the four previously established

Table 3-2 Description of Australian Sorghums (based on Lazarides et al. 1991).

\begin{tabular}{|c|c|c|c|c|}
\hline Subgenus & $\begin{array}{l}\text { Chaetosorghum } \\
\text { Garber }\end{array}$ & $\begin{array}{l}\text { Heterosorghum } \\
\text { Garber }\end{array}$ & $\begin{array}{l}\text { Parasorghum } \\
\text { (Snowden) } \\
\text { Garber }\end{array}$ & $\begin{array}{l}\text { Stiposorghum } \\
\text { Garber }\end{array}$ \\
\hline Species & S. macrospermum & S. laxiflorum & \begin{tabular}{|l} 
S. grande \\
S. leiocladum \\
S. matarankense \\
S. nitidum \\
S. timorense
\end{tabular} & $\begin{array}{l}\text { S. amplum } \\
\text { S. angustum } \\
\text { S. brachypodum } \\
\text { S. bulbosum } \\
\text { S. ecarinatum } \\
\text { S. exstans } \\
\text { S. interjectum } \\
\text { S. intrans } \\
\text { S. plumosum } \\
\text { S. stipoideum }\end{array}$ \\
\hline Distribution & Australia & $\begin{array}{l}\text { Australia, Papua } \\
\text { New Guinea, } \\
\text { Philippines }\end{array}$ & $\begin{array}{l}\text { Arica, Asia, } \\
\text { Australia, Mexico }\end{array}$ & Australia \\
\hline Duration & Annual & Annual & $\begin{array}{l}\text { Chiefly perennials } \\
(3 / 5)\end{array}$ & Chiefly annuals \\
\hline Racemes & 9-21-jointed & Usually 2-jointed & $\begin{array}{l}\text { Usually 3-6(-10)- } \\
\text { jointed }\end{array}$ & 1(-3)-jointed \\
\hline \multicolumn{5}{|l|}{ Sessile Spikelet } \\
\hline \begin{tabular}{|l|} 
Sessile Spikelet \\
Length (incl. \\
callus)
\end{tabular} & $10-11 \mathrm{~mm}$ & $5.3-6.6 \mathrm{~cm}$ & $\begin{array}{l}\text { Usually less than } \\
8 \mathrm{~mm}\end{array}$ & $\begin{array}{l}\text { Usually more } \\
\text { than } 8 \mathrm{~mm}\end{array}$ \\
\hline $\begin{array}{l}\text { Sessile Spikelet } \\
\text { Callus }\end{array}$ & Minute. obtuse & Minute. obtuse & $\begin{array}{l}\text { Small to minute, } \\
\text { Blunt to subacute }\end{array}$ & $\begin{array}{l}\text { Usually } \\
\text { elongated and } \\
\text { pungent }\end{array}$ \\
\hline $\begin{array}{l}\text { Sessile Spikelet } \\
\text { Awn length }\end{array}$ & $3.3-5.2 \mathrm{~cm}$ & $2.5-4.3 \mathrm{~cm}$ & $\begin{array}{l}1-6.5 \mathrm{~cm} \text { or } \\
\text { absent }\end{array}$ & $5-15 \mathrm{~cm}$ \\
\hline $\begin{array}{l}\text { Sessile Spikelet } \\
\text { Lower glume }\end{array}$ & 15-20-nerved & 11-nerved & $\begin{array}{l}\text { Usually 7-9- } \\
\text { nerved }\end{array}$ & $\begin{array}{l}\text { usually 9-11 } \\
\text { nerved }\end{array}$ \\
\hline
\end{tabular}

Table 3-2 contd.... 
Table 3-2 contd....

\begin{tabular}{|l|l|l|l|l|}
\hline Subgenus & $\begin{array}{l}\text { Chaetosorghum } \\
\text { Garber }\end{array}$ & $\begin{array}{l}\text { Heterosorghum } \\
\text { Garber }\end{array}$ & $\begin{array}{l}\text { Parasorghum } \\
\text { (Snowden) } \\
\text { Garber }\end{array}$ & $\begin{array}{l}\text { Stiposorghum } \\
\text { Garber }\end{array}$ \\
\hline $\begin{array}{l}\text { Sessile Spikelet } \\
\text { Caryopsis }\end{array}$ & $\begin{array}{l}\text { Ovoid to } \\
\text { ellipsoid }\end{array}$ & $\begin{array}{l}\text { Obovoid to } \\
\text { ellipsoid }\end{array}$ & Usually obovoid & Variable \\
\hline $\begin{array}{l}\text { Sessile Spikelet } \\
\text { Lodicules }\end{array}$ & $\begin{array}{l}\text { Glabrous or } \\
\text { pubescent }\end{array}$ & Sparsely ciliate & $\begin{array}{l}\text { Ciliate (rarely } \\
\text { glabrous) }\end{array}$ & $\begin{array}{l}\text { Ciliate (rarely } \\
\text { glabrous) }\end{array}$ \\
\hline $\begin{array}{l}\text { Pedicelled } \\
\text { spikelet }\end{array}$ & Reduced, neuter & Reduced, neuter & $\begin{array}{l}\text { Developed, } \\
\text { staminate of } \\
\text { neuter }\end{array}$ & $\begin{array}{l}\text { Developed } \\
\text { (rarely } \\
\text { suppressed), } \\
\text { neuter or } \\
\text { staminate }\end{array}$ \\
\hline $\begin{array}{l}\text { Pedicelled } \\
\text { spikelet } \\
\text { Glumes }\end{array}$ & Slightly unequal & Unequal & Subequal & Subequal \\
\hline $\begin{array}{l}\text { Pedicelled } \\
\text { spikelet } \\
\text { Panicle } \\
\text { branches }\end{array}$ & Usually simple & Divided & Simple of divided & Usually simple \\
\hline $\begin{array}{l}\text { Pedicelled } \\
\text { spikelet } \\
\text { Articulation } \\
\text { joint }\end{array}$ & $\begin{array}{l}\text { Cupular, } \\
\text { horizontal }\end{array}$ & $\begin{array}{l}\text { Cupular, } \\
\text { horizontal }\end{array}$ & $\begin{array}{l}\text { Usually cupular } \\
\text { and horizontal }\end{array}$ & $\begin{array}{l}\text { Usually linear } \\
\text { and oblique }\end{array}$ \\
\hline $\begin{array}{l}\text { Culm nodes } \\
\text { pubescent }\end{array}$ & $\begin{array}{l}\text { Glabrous or } \\
\text { pearded or } \\
\text { pubescent }\end{array}$ & $\begin{array}{l}\text { Pubescent or } \\
\text { bearded, rarely } \\
\text { glabrous }\end{array}$ & $\begin{array}{l}\text { Pubescent or } \\
\text { bearded or } \\
\text { glabrous }\end{array}$ \\
\hline $\begin{array}{l}\text { Pruinosity } \\
\text { flabsent or } \\
\text { sometimes } \\
\text { present }\end{array}$ & $\begin{array}{l}\text { Chiefly 10, 20; } \\
\text { also 30, 40 }\end{array}$ & $\begin{array}{l}\text { Chiefly 10; also } \\
\text { 20, 30, 40 }\end{array}$ \\
\hline Absent & 40 & Present \\
\hline
\end{tabular}

sections, but considered characters relating to indumentum/pubescence on the culm nodes, pruinosity, nervation of the lower glume of the sessile spikelet, lodicules and caryopsis to be of limited taxonomic value. They regarded section Stiposorghum as most advanced with section Parasorghum the most primitive. Parasorghum is characterized by a short, straight blunt callus and cupular articulation joint whereas in Stiposorghum, the callus is longer curved and pungent with a linear joint. While these two sections are clearly delimited, the two monotypic sections Chaetosorghum and Heterosorghum have several features in common as in the minute obtuse calli, more or less circular articulation joints, prominent awns and reduced pedicellate spikelets. Discrimination is based on dissimilarities in habit, glume nervation, relative pubescence, panicle branching and numbers of raceme joints. Glumes of pedicellate spikelets are equal in length and lower glume of sessile spikelets is 10-22-nerved in Chaetosorghum, while the 
glumes of pedicellate spikelets are unequal in length and the lower glume of sessile spikelets is 9-12-nerved in Heterosorghum. Members of the four sections, viz., Chaetosorghum, Heterosorghum, Parasorghum and Stiposorghum are reproductively isolated from those in section Eu sorghum.

\subsection{Reassessment of the Classification of Sorghum}

The number of "species" in the genus Sorghum has long been debated, and differs in published literature with the usual extremes of "lumpers" and "splitters". Wright (1940) defined species as "groups within which all subdivisions interbreed sufficiently to form intergrading populations wherever they come in contact, but between which there is so little interbreeding that populations are not found". Dobzhansky (1951) outlined isolating mechanisms, of which geographical separation was one. Stebbins (1970) confirmed Dobzhansky's treatment of the "species" concept.

It is clear that much of the current classification of the genus depends on studies of the mid 20th century, and only a few studies have been carried out to evaluate the relationship within the subtribe Sorghastrae. Although, this current classification is convenient, phylogenies based on sequence analysis suggest that the Sorghum section designations may not correspond to evolutionary relationships (Spangler et al. 1999; Dillon et al. 2001, 2004). Phylogenetic relationships within the genus Sorghum have been studied from various perspectives: Karyotype and crossability (Garber 1954; Gu et al. 1984), numerical analysis of morphological characters (Liang and Casady 1966), variation of chloroplast restriction sites (Duvall and Doebley 1990), mitochondrial DNA restriction site (Guo et al. 1996), allozyme patterns (Morden et al. 1990), and internal transcribed spacers of nuclear ribosomal RNA (Sun et al. 1994). The ploidy level and number of genomes present in S. bicolor, however, are still not definitive. Furthermore, the diversity and variability of sorghum make it especially difficult to deal with taxonomically.

The literature on the classification of sorghum is confusing. This invites reassessment of the classification of sorghum using nucleotide sequence data. Nucleotide sequence data can provide more discerning classification of sorghum because the mutation process underlying nucleotide polymorphism is better understood. Evaluation of Sorghum taxa in the light of recent molecular and morphological evidence have led to splitting Sorghum into three genera: Sorghum, Sarga and Vacoparis (Spangler 2003). Though the data suggest that the three distinct lineages exist, the relationships among these lineages are unresolved. Each lineage is recognized here as a distinct genus in the context of overall variation in tribe Andropogoneae. The proposed genus Sorghum encompasses species S. bicolor, S. halepense and S. nitidum. The proposed genus Sarga encompasses 
species presently found in the subgenera Parasorghum and Stiposorghum. The proposed genus Vacoparis encompasses Australasian taxa, V. macrospermum and $V$. laxiflorum. Uncertain relationships among the three lineages exemplify the difficulties in assigning ranks to taxa that may cause future dramatic name changes with new data. As discussions progress concerning the validity and utility of rankless classifications, concrete examples can provide insights into specific cases where strengths and weaknesses can be evaluated. Species boundaries in Sarga are different from those defined formerly. Continuous variation across specimens in characters used to distinguish taxa in the past led to the decision to broaden species limits so that fewer and morphologically variable species are recognized (Spangler 2003). The limitations of the available sequence-based phylogenies imply that this reclassification is premature.

A detailed investigation of phylogenetic relationships within Sorghum (Dillon et al. 2004) revealed that the Eu-sorghum species resolves into a strong lineage, which also includes the Australian natives S. laxiflorum and S. macrospermum. This makes the two Australian wild sorghum species most closely related to cultivated sorghum. The remaining wild relatives of cultivated sorghum strongly resolve to a second lineage. Their data support a reduction in the number of subgeneric sections from five to three: Sorghum (unchanged), a combined Chaetosorghum/Heterosorghum to reflect the very close relationship between these two species, and a combined Parasorghum / Stiposorghum section, thereby removing the unclear taxonomic and genetic boundaries between these species.

Traditional taxonomic treatment of Sorghum based on morphological characters has generally resulted in a classification clustered with Latin names that have little or no biological meaning, and some individual taxa are given ranks that seem contradictory. This has probably caused more difficulty in understanding the origin and evolution of cultivated sorghum than any other factors. With recent Sorghum phylogenetic analyses providing new insights, it is our opinion that there is need to reassess the classification that is based on a hierarchy of formal ranks, and probably reclassify sorghum on a clade-basis, which perhaps will better reflect the branching pattern of evolution. However, the major task will be to incorporate the resulting patterns of cladistic analysis into already existing hierarchical sorghum classification.

\subsection{Origin, Domestication, Evolution and Diversity}

Sorghum indisputably, originated in Africa where the greatest diversity of both wild and cultivated types exist (Doggett 1988; de Wet and Harlan 1971; de Wet 1978). The earliest known record of wild sorghum, dated about 8000 BP, comes from an archaeological site at Nabta Playa near the Egyptian 
-Sudanese border (Dahlberg and Wasylikova 1996). Wild and weedy Sorghum within Eu sorghum are believed to have significantly contributed to the sorghum domestication probably in the Ethiopian highlands of the northeast quadrant of Africa. Snowden (1936) believed that wild races aethiopicum, arundinaceum and verticilliflorum independently gave rise to the cultivated races durra, guinea and kafir, respectively, in eastern, western and eastern-central Africa respectively. de Wet and Huckabay (1967) based on comparative morphology and natural distribution data, came to a similar conclusion, but opined that the durras probably arose from the kafirs. Based on similarity coefficients they pointed out that race verticilliflorum had affinities with all cultivated races though closest to the kafirs. Harlan and Stemler (1976) in an attempt to understand the domestication process, collected and classified both the wild and cultivated races from their native habitats and based on morphology, ecology and distribution, Harlan (1992) surmised that race verticilliflorum being the most widely distributed of all the races was probably the primary progenitor for cultivated sorghum as opposed to race arundinaceum which flourishes best in areas too wet and humid for cultivated sorghum. Harlan (1992) however did not rule out some genetic contribution from the other races since all of the races both cultivated and wild belong to one biological species. By his postulate, an early bicolor type was first domesticated from race verticilliflorum in the Chad-Sudan region; this spread to West Africa where the guinea race evolved through introgression with race arundinaceum; and to South Africa where the kafir evolved; he also suggests that durras probably arose in India from the first introduced bicolors. Electrophoresis data suggest that kafirs are close to the race verticilliflorum (Schecter and de Wet 1975). Doggett (1988), however, maintains that the durra is of Ethiopian origin since the entire spectrum of wild type bicolor-durra crosses is found there. Race caudatum is referred to as a later domesticate and Doggett (1988) proposes that it could have arisen from a continued interaction with the wild genepool in the Ethiopian region. The kaoling of China is also thought to be derived from race bicolor introduced there or alternatively it may have been derived from cross compatible wild diploid sorghums (S. propinquum) (Harlan 1995). Systematic relationships revealed by nuclear and chloroplast restriction site analysis indicate that cultivated sorghum is derived from wild subsp. verticilliflorum. When exactly sorghum was domesticated in Africa is still unclear. So far, remains of African domesticated sorghum have been dated at about 100 AD at Qasr-Ibrim, Egyptian Nubia (Rowley Conwy 1991; Rowley Conwy et al. 1997; Clapham and Rowley Conwy 2007).

Early domestication of sorghum was associated with changing the small seeded shattering open panicles towards non shattering and more compact panicles. This involved several factors: significant increase in number of branches within the inflorescence, decrease in the internode length of the 
rachis and an increase in seed size so it protruded out of the glumes (House 1985). These changes contributed to increased yield in domesticated types as compared to the ancestral forms. Immense morphological diversity in cultivated sorghum has emerged because of variable climate and geographical exposure in which the wild ancestors evolved, coupled with selection pressures imposed both by diverse environments and by man during the domestication and ennoblement process (Doggett 1988). Sorghum is reported to have spread from Africa to India via the Middle East through trade routes some 3000 years ago (Mann et al. 1983), to China and the Far East via the Silk route ( 400AD) and to the Americas with the slave trade (1800s-1900s). In India, regarded as the secondary center of diversity, the earliest remains of cultivated sorghum are dated as early as the second millennium BC (Fuller 2002) and considerable diversity particularly of the durra and halfdurra types has evolved and developed in the region. In Australia, cultivated sorghum was only introduced around the 1900s. However, the higher rainfall region of the northern territory, in which endemic taxa are represented to a high degree, appears to be a center of diversity for the Australian representatives of the genus (Lazarides et al. 1991).

Sorghum has been extensively investigated for understanding taxonomic relations and evolution of the crop. Early studies focused on morphology, cytology and distribution data, primarily, of the African component of the wild sorghum (Snowden 1936, 1955; Liang and Casady 1966; de Wet et al. 1970; de Wet and Huckabay 1967; de Wet and Harlan 1971; de Wet 1978; Harlan 1992), which helped in circumscribing species limits, and explaining the origin and domestication process. The deployment of environmentneutral molecular tools in recent times combined with advanced statistical methods has contributed considerably to further our understanding of sorghum domestication and levels of diversity within the genepool. Studies using a variety of molecular markers including isozymes (Morden et al. 1990; Aldrich et al. 1992), Restriction Fragment Length Polymorphisms (RFLPs), Random Amplified Polymorphic DNAs (RAPDs), Inter-Simple Sequence Repeats (ISSRs) (Aldrich and Doebley 1992; Cui et al. 1995; de Oliviera et al. 1996), mitochondrial DNA (Deu et al. 1995), Amplified Fragment Length Polymorphisms (AFLPs) and Simple Sequence Repeats (SSRs) (Kamala 2003; Casa et al. 2005, 2008; Billot et al. 2013) have confirmed previous concepts of sorghum domestication/evolution, although assessed levels of diversity have varied with different marker systems. For example, Deu et al. (1995) showed that the diversity observed in 109 cultivated types (subsp. bicolor) was encompassed within the 47 wild relatives (subsp. verticilliflorum and S. halepense); Casa et al. (2005) using SSRs indicated that landraces retained $86 \%$ of the diversity observed in the wild sorghum but they were less diverse than the wild. Although the landraces and wild were moderately 
differentiated (Fst=0.13), there was little evidence of population differentiation among racial groups of cultivated sorghum ( $\mathrm{Fst}=0.06)$; statistical methods for identifying genomic regions with patterns of variation consistent with selection gave significant results for 11 loci, seven of which mapped in or near genomic regions associated with domestication-related Quantitative Trait Loci (QTLs) (i.e., shattering, seed weight and rhizomatousness). Billot et al. (2013) genotyped a large global sorghum collection (3,367 accessions) including landraces $(89.5 \%)$, breeding lines or advanced cultivars $(8.3 \%)$, wild/weedy types $(2.0 \%)$ and unknown $(0.1 \%)$ using 41 SSRs; 17 markers produced alleles unique to wild/weedy accessions. Forty of the 783 alleles were unique to wild species, with three of them found in one accession of S. propinquum; wild and weedy types captured 57 and $65 \%$ of the detected alleles respectively, with no clear separation of wild and cultivated types, showing that there was considerable gene-flow between them. In summary, wild sorghum from Northeastern and Central Africa exhibit greater genetic similarity to cultivars than do the wild sorghum of Northwestern or southern Africa confirming that wild sorghum of Northeastern and Central Africa is ancestral to the domesticated sorghum; S. halepense probably originated via autopolyploidy or segmental allopolyploidy; wild and cultivated genepools are distinct with greater diversity in the wild sorghum than in the cultivated genepool thus lending credence to the fact that cultivated sorghum experienced a loss in diversity during domestication. Nevertheless, all these assessments have indicated that sorghum has an unusual amount of diversity. Multiple origins for domesticated sorghum, cross-pollination between selected races, and outcrossing between domestic cultivars and highly variable wild species all are considered factors contributing to the extensive genetic diversity observed in sorghum (Doggett 1988). Recent studies show that sorghum displays a mixed mating system, and out crossing especially in the wild types can vary from zero to almost $100 \%$ (Ell strand and Foster 1983; D'je et al. 2004; Muraya et al. 2011; Aduguna et al. 2013). Out crossing between wild and cultivated sorghum appears to have been more important than migration via seed dispersal as a mechanism for gene flow between the wild and domestic accessions. Muraya et al. (2011) showed that long distance seed-mediated gene flow lead to a weak regional sorghum differentiation, reflecting the importance of human intervention in shaping the population structure and diversity through seed-mediated gene flow, which can render geographical boundaries irrelevant. The population structure of modern sorghum appears to fit well into Wright's "shifting balance" theory of adaptation, which assumes that genetic drift and selection operating on subpopulations leads to a number of genotypes occupying different adaptive peaks, even though gene flow can occur between the subpopulations (Wright 1931,1932, 1978). Wright's theory has been widely accepted to explain plant evolution and speciation (Hartl and 
Clark 1989), including applications to the evolution of sorghum (Doggett and Majisu 1968; Doggett 1988; Cui et al. 1995).

\subsection{Genetic Resources, Genepools and Conservation Perspectives}

Novel germplasm can be used in breeding programs to create new crops and new uses for existing crops, to meet breeding objectives for sustainability of crop production, and to ensure that the entire world's people benefit from crop improvement through enhanced food security and quality (HeslopHarrison 2002). Given the importance of sorghum in the semi-arid tropics, an ex situ collection for sorghum was initiated in the 1960s by the Rockefeller Foundation as part of the Indian Agricultural Research Programme, which was transferred to ICRISAT, Patancheru, India in 1974 (Stenhouse et al. 1997). Three decades ago, the danger of genetic erosion in traditional landraces due to the release of new varieties and hybrids increased the collection and conservation efforts throughout the world. Concomitantly, there was a heightened awareness of the importance of wild species in crop improvement, and both National and International gene banks began augmenting their collections with wild relatives. At present the ICRISAT sorghum collection, which is one of the largest, contains 458 accessions of wild sorghums belonging to 13 species besides 37,904 accessions of cultivated sorghum from 91 countries. Landraces constitute $85.3 \%$, breeding material $13.2 \%$, wild species accessions $1.2 \%$ and named cultivars $0.3 \%$ of the total collection. Harlan and de Wet's collection of wild sorghums including several of the diploid wild races, collected from their natural habitats, was obtained from Mayguez, Puerto Rico, USA in the early 60s (http://www. icrisat.org), form a part of ICRISAT's collection. Wild sorghums in the US sorghum collection include 435 accessions of about 10 species, which is about $1 \%$ of their entire sorghum collection of 45,904 (http:/ / www.ars-grin. gov). Collections of wild species ( 358 accessions of 22 species; $7 \%$ of total holdings) are also maintained at the Australian Tropical Crops and Forages Genetic Resources Centre, Biloela, Australia (AusPGRIS 2013), which is by far the largest collection in terms of representatives of the Australian wild sorghums. The National Bureau of Plant Genetic Resources (NBPGR) in India has about 20,000 collections of which only $0.1 \%$ are designated as wild material (www. nbpgr.ernet.in); while the Institute of Crop Germplasm Resources (ICGR) in China holds around 16,874 collections (http:/ / www. icgr.caas.net.cn/cgris_english.html). In addition, there are about 30 other institutions holding ex situ sorghum collections (http://apps3fao.org/ wiews). However, very few of these have wild material (KARI, Kenya-92; NIAS, Japan-13, SRGB, Zambia-27).

Harlan and de Wet (1971) proposed three informal categories or genepools (primary, secondary and tertiary) based on ease of crossability 
between species: the primary genepool includes all cultivated sorghum and their wild and weedy relatives with $2 n=20$ chromosomes (S. bicolor complex) along with the diploid perennial S. propinquum. The secondary genepool comprises $S$. halepense, which is an autotetraploid species that is reported to have probably arisen from a cross between S. propinquum and S. verticilliflorum (Doggett 1988). The tertiary genepool contains members of all other sections of sorghum $(2 n=20,30,40)$ as well as related genera - Saccharum, Zea, Cliestachne and Sorghastrum (Fig. 3-1).

For sorghum, the primary and secondary genepool species are somewhat represented in the few ex situ collections, but since all the species are relatively widespread, they are not a high conservation priority (Maxted and Kell 2009). The USDA, ARS, National Genetic Resources Program (2013) reports the following distributional information: S. bicolor subsp. drummondii "may occur as a weed wherever sorghum is cultivated"; S. bicolor subsp. verticilliflorum is widely distributed in Africa and naturalized in India Australia and the Americas; S. propinquum is distributed in India, Sri Lanka, Indochina, Myanmar, Thailand, Malaysia and the Philippines; S. halepense is distributed in northern Africa, western Asia, the Caucasus, former Soviet Union, Middle Asia and India, and is naturalized in warm-temperate regions, including North America. S. bicolor subsp. drummondii, and S. halepense are also classified as noxious weeds in the United States (USDA, ARS, National Genetic Resources Program 2013). The tertiary genepool species are primarily conserved in the Australian Tropical Crops and Forages Genetic Resources Centre, Biloela, Australia. While some species are represented by as many as over 40 accessions (S. stipoideum-42; S. timorense-43; S. plumosum-56), there are very few of others such as $S$. grande (1), S. amplum (1), S. macrospermum (3). Given the growing recognition of the potential and significance of these wild species in sorghum improvement, there is an urgent need to analyze where gaps in ex situ collections and research exist relative to diversity hotspots of these wild species, in order to identify and prioritize targeted collection of poorly represented species throughout the range of their distribution.

Historically, genetic resources have primarily been conserved using ex situ methods, with most attention having been given to collecting and maintaining landraces, traditional/obsolete cultivars, breeding lines and genetic stocks (Frankel and Bennet 1970; Frankel 1973; Frankel and Hawkes 1975; Guarino et al. 1995; Hawkes et al. 2000; Smith et al. 2003). That wild relatives were very poorly represented in ex situ collections worldwide was particularly highlighted in The Second Report on the State of the World's PGRFA (FAO 2010). Recent research has questioned whether landrace diversity can be effectively conserved ex situ due to the genetic bottleneck associated with sampling and multiplication/regeneration in gene banks and the constantly and relatively rapidly changing genetic diversity within 
populations (Negri and Teranti 2010). Similarly, it is also widely agreed since the inception of the CBD that in situ conservation should be the primary conservation strategy, with ex situ employed as a backup, because in contrast to ex situ conservation, in situ conservation promotes natural gene exchange and continued evolution of landraces and crop wild relatives populations (CBD 1992; Brush 1995; FAO 1996, 2001; Maxted et al. 1997a; Heywood and Dulloo 2005; Stolton et al. 2006; Negri et al. 2009).

Recent studies on crop wild relatives indicate how susceptible they could be to climate change. Jarvis and colleagues (2008) indicate that wild peanut species in South America, wild cowpeas in Africa, and wild potatoes in Central and South America will lose half their current geographic ranges and that between 16 and $22 \%$ of these species will go extinct. Conservation of wild relatives has started to be addressed by various national and international initiatives, including the International Union for Conservation of Nature's Crop Wild Relative Specialist Group (www. cwrsg.org), a Global Environment Framework project ("In situ conservation of crop wild relatives through enhanced information management and field application"; www.cropwildrelatives.org/index.php?id=3261), the crop wild relative global portal, the Food and Agriculture Organization of the United Nations' initiative to establish a global network for the in situ conservation of CWR diversity (Maxted and Kell 2009), and the European Union-funded European Crop Wild Relative Diversity Assessment and Conservation Forum (www.pgrforum.org).

\subsection{Utilization}

Availability of adequate genetic variation is a fundamental prerequisite for genetic improvement of any crop species. Estimation of genetic diversity to identify groups with similar genotypes is important for conserving, evaluating and utilizing genetic resources, to select possible sources of genes that can improve the performance of cultivars, and to determine the uniqueness and distinctness of phenotypes and genotypes with the purpose of protecting the breeder's intellectual property rights (Subudhi et al. 2002). In the past, plant breeders selected breeding material based on morphological characteristics that were readily observable and co-inherited with the desired traits. However, recent technological advancements have made it possible for genomic resources to be deployed in sorghum improvement efforts worldwide. An accurate assessment of the genetic variation in a genepool provides an objective basis to design efficient and cost-effective crop improvement strategies for sustainable long-term selection gains. Moreover, an assessment of the degree and distribution of this variation, conceptualized usually as "allele richness" and "allele evenness", allows a better understanding of evolutionary relationships 
and permits an objectively targeted utilization of crop genetic resources for breeding and conservation. A combination of morphological and molecular analyses on large samples and smaller samples, respectively, would maximize both information and usefulness (Hillis 1987). Such analyses provide a basis for making informed decisions regarding the management and utilization of genetic resources. More importantly, molecular diversity data can potentially bridge conservation and use when employed as a tool for mining germplasm collections for genomic regions associated with adaptive or agronomically-important traits (i.e., genes that have been important in adaptation to local environments or are associated with phenotypes selected by farmers or breeders (Casa et al. 2005).

Utilization of genetic variation via artificial selection through plant breeding programs has resulted in major advancements in agricultural productivity. However, for continued success in crop improvement, new sources of genetic variability are required to be incorporated into breeding programs to enhance selection gains. Continuous use of elite germplasm by the plant breeders tends to narrow the genetic diversity and thus slow breeding progress (genetic gain per cycle of selection) and increased risk of crop vulnerability. This is exemplified by the Irish potato famine, during 1845-49 caused by late blight, and more recently the southern leaf blight epidemic in the US maize crop in 1970 (Hawkes et al. 2000).

Traditionally, plant breeders have sought to broaden the genetic base of crop plants from secondary or even tertiary genepools using wide crosses when required traits or levels of diversity in the cultigens are not easily accessible and/or available. An analysis of the numbers of reported uses of crop wild relatives in plant breeding in the last five decades showed that only five reported uses in the 1960s rising to over 100 cited uses since 2000 (Maxted and Kell 2009). The traits contributed by wild relatives of various crops to improvement have been listed (Maxted and Kell 2009). Wild species have been most widely used as sources of resistance or tolerance to pests and diseases (Harlan 1984; Goodman et al. 1987; Prescott-Allen and Prescott Allen 1988; Hoyt 1988; Maxted et al. 1997a; Meilleur and Hodgkin 2004; Stolten et al. 2006; Dwivedi et al. 2008). The genetic potential of wild species particularly in resistance breeding is well documented for crops such as wheat, rice, maize, barley, potato, tomato, tobacco and sugarcane among others (Hawkes 1977; Stalker 1980; Pluknett et al. 1987). Alien genes have successfully been transferred for improvement of cultivated cereals, including rust resistance in bread wheat (Knott 1971), grassy stunt resistance in rice (Khush 1977), mildew and crown resistance in oats (Browning and Frey 1969; Aung and Thomas 1976) and for increased biomass and grain yield in oats and pearl millet (Frey 1983). In Israel a study has showed greater diversity in wild and weedy barleys (Hordeum vulgare subsp. spontaneum) than in a composite cross of cultivated barleys that included over 6,000 
cultivars in its parentage (Nevo et al. 1979). In genera such as Saccharum, Solanum section tuberosum, Glycine, Gossypium, Arachis, Lycopersicon, Hordeum and Triticum, though they range beyond the ecological zones of their cultivated species, wild species have been profitably exploited by plant breeders.

Much of research in sorghum has been geared toward cultivated sorghum and studies in wild sorghum are limited. The idea that wild sorghum could be used to broaden the adaptability of the cultivated sorghum is mainly based on its wide range of ecological adaptation. The race arundinaceum flourishes in African rain forests, whereas cultivated sorghum are very poorly adapted (Harlan 1992). Such germplasm has been shown to be more photosynthetically efficient at low light intensities than cultivated sorghum (Downes 1971). Race virgatum is known to extend into the fringes of the desert, thriving naturally beyond the range of the crop and could be a source of drought tolerance. Indeed, seeds of race virgatum are known to germinate at very high temperatures, a trait often important to stand establishment in high temperature regions (Bramel-Cox and Cox 1988). Lazarides et al. (1991) reported that the indigenous Australian sorghum are extensively distributed in the monsoonal region, occurring over extensive areas as major components of grassland, woodland and forest communities, with some exceptions (S. timorense, S. macrospermum and S. grande which are habitat specific), are ecologically widely adaptable. Bramel-Cox and Cox (1988) showed the possibility of increasing sorghum yields through transfer of genes from races virgatum, arundinaceum and verticilliflorum.

The search for new resistance genes is an ongoing important process since pest/pathogen populations continue to change their virulence patterns. For sorghum, which is constrained by over 40 diseases and 150 insect pests (Jotwani et al. 1980; Frederiksen and Duncan 1982), host plant resistance offers an effective, economical and environment friendly method of pest/pathogen control since it does not involve any additional investments by the resource poor farmers. Kamala et al. (2002) reported 36 potentially new sources of resistance genes from wild and weedy sorghums that could be used to develop resistant cultivars to control sorghum downy mildew Peronosclerospora sorghi Weston and Uppal (Shaw) (SDM) which causes serious yield losses. Accessions belonging Chaeto-, Hetero-, Stiposorghum and the Australian Parasorghum, constituting the tertiary genepool, were immune to the disease in greenhouse studies. The Afro-Asian species (S. versicolor and S. purpureosericeum) along with S. nitidum were also highly resistant but accessions of these species have been reported as susceptible elsewhere; Bonde and Freytag (1979) found S. versicolor from Ethiopia was susceptible to an American isolate of P. sorghi and Bonman et al. (1983) reported that native $S$. nitidum from Thailand was highly susceptible. 
Resistance to SDM has not been observed as a common trait among the cultivated sorghums. Only about 130 accessions were identified as resistant to the ICRISAT culture of the SDM pathogen in a screening of over 16,000 accessions from the world sorghum collection at ICRISAT (Pande et al. 1997). The distribution of resistant sources within section Eu sorghum (Africa 80\%; India 8\%; USA and Australia 12\%) appears to validate the generally accepted view that resistance to many diseases/pests is not randomly distributed, but may be found in specific geographical/regional pockets/centers of diversity especially where the crop host and the pathogen have co-evolved (Leppik 1970; Harlan 1977). Africa is the center of domestication as also the primary center of diversity of the crop, while India is a secondary center. Africa is also probably the primary center of diversity of the pathogen (Williams 1984), so the region is likely to harbor greater diversity for SDM resistance. Several pathotypes with varying virulence patterns have been identified (Craig and Fredericksen 1980; Fernandez and Schaffert 1983; Pawar et al. 1985; de Milliano and Veld 1990; Craig and Odvody 1992). In Australia, since the disease has not been reported until very recently (Pande et al. 1997) resistance in the endemic wild Australian species seems to have developed in the absence of the pathogen signifying allopatric resistance (Harris 1975). Although P. sorghi is unknown, another downy mildew causing species P. noblei is known on S. plumosum, from temperate New South Wales, Australia (Weston 1942; Kenneth 1981). In addition, $P$. sacchari, causing downy mildew of sugarcane is also reported. There are no reports on the susceptibilities of other indigenous Australian sorghum to these pathogens. A comparison of the host ranges of a relatively large number of isolates of P. sorghi on the same species/accessions of Parasorghum, Heterosorghum, Chaetosorghum and Stiposorghum coupled with mycological comparisons could help to determine differential susceptibilities of various species of Sorghum to downy mildew.

While most of the wild and weedy sorghums of Eu sorghum are highly susceptible, two accessions (one each in races aethiopicum (IS 18821) and arundinaceum (IS 18882), and one weedy accession of S. halepense (IS 33712)] were also free from downy mildew. These may be directly used in sorghum breeding to incorporate SDM resistance and produce durable resistance for areas where downy mildew is a serious problem. They may also profitably be used to generate mapping/segregating populations to identify the gene/s or QTLs associated with SDM resistance to enhance marker-aided selection in sorghum improvement. Even though wild races of Sorghum are not priority choices for yield genes in the short term, their potential for improving resistance/tolerance to SDM and other stress environments could prove useful.

Low to moderate levels of resistance to insect pests in cultivated germplasm coupled with breakdown of resistance due to increased insect 
pressure and changing virulence patterns underscore the need to develop cultivars with broad-based resistance utilizing genes from diverse sources (Sharma et al. 2005). Recently, Kamala and her associates have documented in fair detail the resistance responses of wild and weedy sorghum to the shoot fly, Atherigona soccata Rond. (Kamala et al. 2009) and the spotted stem borer, Chilo partellus Swinhoe. (Kamala et al. 2012) along with the mechanisms of resistance involved. They identified 32 accessions belonging to Parasorghum, Stiposorghum and Heterosorghum that did not suffer any shoot fly damage under field conditions while one accession each of Heterosorghum (Sorghum laxiflorum) and Chaetosorghum (S. macrospermum) suffered very low shoot fly damage. Under greenhouse conditions the same accessions either showed absolute non-preference for oviposition under no-choice conditions or were preferred for oviposition, but suffered low deadheart formation. Among the Parasorghum there were varying levels of egg-laying but high larval mortality. A few accessions within section Eu Sorghum also showed significantly reduced survival and fecundity of the larvae. This is promising since none of the existing resistant cultivars is known to be completely non preferred for egg laying. Sorghum purpureo-sericeum and $S$. versicolor of Indian and African origin, respectively, have been reported earlier also to possess high levels of resistance to the shoot fly (Bapat and Mote 1982; Mote 1984; ICRISAT 1995). While oviposition non preference is the primary mechanism of resistance to shoot fly, $A$. soccata in cultivars, there is strong evidence that antibiosis is an important mechanism of resistance in wild relatives of sorghum. Antibiosis in combination with ovipositional non preference would be highly desirable as operating mechanisms for resistance to shoot fly. In view of the immunity/high resistance observed in these wild sorghums, the exact nature of the resistance conferred by these species needs to be unravelled by further studies and biochemical assays for a better understanding of shoot fly behavior, particularly in relation to its host species.

Several of the wild species from Africa, Asia and Australia have also been identified as having high levels of resistance to the spotted stem borer, C. partellus (Kamala et al. 2012). Wild species belonging to Heterosorghum, Parasorghum and Stiposorghum suffered very low stem borer damage while those of Chaetosorghum and Eu sorghum were highly susceptible to stem borer damage, suffering very high levels of leaf damage and plant deadhearts. Wild races/species in Eu sorghum are common hosts of stem borers under natural conditions (Reddy 1985) and probably serve as alternate hosts/ reservoirs of this insect. Studies have reported that indigenous wild grasses in Africa are major hosts for the spotted stem borer, with higher levels of oviposition on napier grass, blue thatching grass and vetiver grass as compared to that on cultivated maize or sorghum (van den Berg 2006; Rebe et al. 2004; Muyekho et al. 2005). Chilo partellus has also been 
shown to develop on Sudan grass (Khan et al. 2000) and S. arundinaceum, indicating their suitability as hosts. Sorghum versicolor is interesting since its members show both resistance (Kamala et al. 2012) and susceptible responses (Muyekho et al. 2005). Therefore, these wild species that are preferred for oviposition, but unsuitable for larval development, have a considerable potential for use in management of stem borers in cultivated sorghum by acting as a barrier crop.

Several of the Australian species of sorghum have also been shown to possess high levels of resistance to the sorghum midge, Stenodiplosis sorghicola (Coquillett) (Harris 1979; Sharma and Franzmann 2001) besides resistance to the shoot fly and spotted stem borer. The adaptability of the undomesticated Australian Sorghum species to colonize a wide range of soil and moisture conditions across a wide range of microenvironments is shown through their ability to survive very hot, dry, nutrient-limited environments (Dillon et al. 2007b). Interestingly, many Australian undomesticated species contain resistances to the major pest/diseases of Africa, Asia and America, which are not yet present within Australia notably the sorghum downy mildew, shoot fly, sorghum midge and spotted stem borer. This again supports the idea of allopatric resistance - that a recent co-evolutionary history is not necessary for a plant to possess resistance to a pest. Rather, resistance may be a consequence of a separate biological process important to plant survival, and incidentally also affording resistance to an insect with which it has had no co-evolutionary history. However, it is also possible that infestation by $A$. soccata or C. partellus is restricted to section sorghum as is reported for Stenodiplosis sorghicola Coquillett (Sharma and Franzmann 2001). Similarly, Harris (1979) studied a wide array of midge specimens collected from sorghum, wild sorghums, wild Poaceae and Cyperaceae from Australia and concluded that species other than Contarinia sorghicola have evolved as specific pests of parasorghums and stiposorghums. Contarinia plumosi and C. roperi are reported to infest Sorghum plumosum, and C. intrans infests S. intrans and S. stipoideum. Other species of gramineae are infested by different species of midges. In the light of this, the response of the Hetero-, Chaeto-, Para- and Stiposorghums to other species of Atherigona and Chilo need to be investigated to enable a better understanding of host plant-insect relationships.

Within the primary and secondary genepools, most of the green bug [Schizaphis graminum (Rondani) (biotype C)] resistant hybrids grown in the USA have been derived from the race virgatum of S. bicolor ssp. verticilliflorum, and highest levels of antibiosis to biotype $\mathrm{E}$ were found in S. halepense (Duncan et al. 1991). Striga-resistance mechanisms such as low germination stimulant production, germination inhibition, and low haustorial initiation activity have been reported to occur in wild sorghum (Rich et al. 2004). 
Sorghum halepense, a wild perennial polyploidy resulting from natural hybridization between S. bicolor and S. propinquum, finds occasional use as forage and even food (seed/flour) but is most noted as one of the world's most noxious weeds, having spread from its West Asian center of diversity across much of Asia, Africa, Europe, North and South America and Australia. While $S$. halepense may be one of the world's worst weeds, the potential use of its allelopathic property is well documented by several investigators (Alsaadawi et al. 1986; Panasiuk et al. 1986; Einhellig and Souza 1992; Ben-Hammouda et al. 1995; Forney and Foy 1985). Both Johnsongrass and Sudan grass reduce the growth of weeds and can contribute to reduction of chemical herbicides. There is, however, a potentially negative aspect of growing these species: they are known to inhibit the emergence or development of nearby or subsequently planted annual and perennial plants (Geneve and Weston 1988).

Besides host plant resistance, recent evaluations of native Australian sorghums have revealed great diversity in grain morphology (seed size and shape), nature of endosperm, distribution of protein bodies throughout the endosperm, shape and size of starch granules (Shapter et al. 2008, 2009a). Good grain starch properties in wild sorghum could be used to improve feed or food digestion efficiency in cultivated sorghum (Dillon et al. 2007b). Increased protein in the starchy endosperm of the wild species may have implications for digestibility for human and animal consumption and may also be a unique adaption for supporting germination in low nitrogen soils (Schapter 2009b).

Sorghum has genome size of about $740 \mathrm{Mb}$ (Paterson et al. 2009). Sorghum is of particular importance as a diploid model for the Saccharinae clade of grasses that includes recently formed complex polyploids such as Saccharum and Miscanthus (Heaton et al. 2008). Each of these polyploids share substantial genetic colinearity and synteny with sorghum (Ming et al. 1998; Kim et al. 2012), and Saccharum QTL often show positional correspondence to those of sorghum (Ming et al. 2001, 2002). One of the few crops suited to all proposed approaches for renewable fuel production, i.e., from starch, sugar, and/or cellulose, sorghum itself is presently the number two US source of fuel ethanol from grain (after maize) and is a promising cellulosic biofuel crop (Rooney et al. 2007). Sorghum bicolor $\mathrm{x}$ Sorghum propinquum is thought to be the widest euploid cross that can be made with the cultigen (S. bicolor) by conventional means, and interspecific populations from these species offer opportunities to genetically dissect a wide range of traits related to plant domestication and crop productivity, some of which have begun to receive attention (Chittenden et al. 1994; Lin et al. 1995, 1999; Paterson et al. 1995; Hu et al. 2003; Feltus et al. 2006). The opportunities offered by comparison of S. bicolor and S. propinquum have led to much effort to develop genomics resources, including a detailed 
genetic map (Chittenden et al. 1994; Bowers et al. 2003), bacterial artificial chromosome-based physical maps for both species (Lin et al. 1999; Draye et al. 2001; Bowers et al. 2005), Expressed Sequence Tag (EST) resources (Pratt et al. 2005), and a genome sequence (Paterson et al. 2009). Among many other aspects of growth and development, S. bicolor and S. propinquum differ in characteristics related to perenniality, a life history strategy for which the sorghum genus has become a model (Paterson et al. 1995; Hu et al. 2003; Jang et al. 2009). Both consideration of how to expand agriculture to provide plant biomass for production of fuels or chemical feedstocks (Tilman et al. 2009) and strategies to rebalance food production with preservation of ecological capital (Glover et al. 2010), focus heavily on perenniality. Demonstration that most genes responsible for variations in size and number in Sorghum and Oryza of an important perennation organ, the rhizome, map to corresponding chromosomal locations (Hu et al. 2003), suggests that information about rhizomatousness from a few models (that are also major crops) may extrapolate broadly to a wide range of taxa.

\subsection{Strategies to Maximize Utilization}

Exchange of genes has tended to be the most effective when the wild species are close relatives of the crop, or are even direct ancestors of domesticated species. Although historically trait transfer from wild relatives to crops was often seen as difficult due to cross incompatibility, hybrid sterility and linkage drag (Stebbins 1958; Zeven et al. 1983), recent technological advances have improved the ease of transfer of traits between distantly related species and expanded the value of wild relatives by increasing their usefulness into the secondary and tertiary crop gene pools (Meilleur and Hodgkin 2004). The wild progenitors of crop plants, their wild and weedy forms (primary genepool) (Harlan and de Wet 1971) and the distantly but cross-compatible wild related species, leading to partially fertile cross-progenies (secondary genepool) have been used in major plant improvement programs (Stalker 1980; Chang 1985; Goodman et al. 1987; Khush and Brar 1988). The use of the tertiary genepool where fertile hybrids are realized only with difficulty are much fewer.

Sorghum improvement has hitherto relied on exploitation of variability within the primary genepool as gene transfer from one background to another can be made quite readily. S. halepense and S. propinquum each naturally introgress with cultivated sorghum and their wild races (Celarier 1958; de Wet 1978), making the use of the few wild taxa in conventional breeding programs possible. Even so, most sorghum improvement has been achieved within grain sorghum races of the same species or closely related species within the same section. The wild species of the other four sections fall within the tertiary genepool, making gene transfer to domesticated 
species very difficult due to strong sterility barriers (Harlan and de Wet 1971) and wide crosses with the wild sorghums outside Eu sorghum have largely been unsuccessful (Duncan et al. 1991; Rosenow and Dahlberg 2000). The strong reproductive barrier to interspecific hybridization is associated with adverse pollen-pistil interaction leading to abnormal pollen tube growth (Sun et al. 1991; Huelgas et al. 1996; Shivanna and Seetharama 1997; Hodnett et al. 2005) and hybrid failure (Kuhlman et al. 2008). Nwanze et al. (1990) reported that a few $\mathrm{F}_{1}$ seeds were obtained in a cross between S. dimidiatum (parasorghum) and cultivated sorghum with varying degrees of sterility. More recently, Price et al. $(2005,2006)$ overcame the reproductive barrier by using cytoplasmic male-sterile $S$. bicolor plants homozygous for the iap (inhibition of alien pollen) allele. This S. bicolor accession had allowed maize (Zea mays L.) pollen tubes to grow through S. bicolor pistils (Laurie and Bennett 1989). Hybrids between S. bicolor x S. macrospermum Garber were obtained from germinated seeds, while the hybrids between S. bicolor $\times$ S. angustum Blake and S. bicolor $\times$ S. nitidum (Vahl) Pers. were recovered through embryo rescue and tissue culture. The hybrid nature of these seedlings was again confirmed by the presence of genomes from both parental species that could be readily identified based upon chromosome size and number (Price et al. 2006). This technique can now be used to introgress desirable traits into cultivated sorghum. Kuhlman et al. (2008) have also recently successfully crossed S. bicolor with S. macrospermum, further opening the possibility of successful wild species use in sorghum breeding. The use of wild relatives in sorghum breeding is still in the early stages, but sorghum wild relatives do offer a range of desirable traits and the recent findings that the recessive iap allele circumvents pollen-pistil incompatibilities auger well for utilizing the enormous potential that exists within the wild sorghum gene pool.

\subsection{The Future}

The wild relatives of crop plants, for all their proven value and obvious potential, have not been fully utilized. Lack of awareness about the potential, pattern of variability, reproductive biology, the knowledge and aptitude for identification, etc. are the major difficulties associated with different breeding programs while using germplasm of wild relatives. Nevertheless they constitute an enormous reservoir of genetic variation for crop improvement and are a critical resource for sustaining food security. Genes from wild plants have provided crops with resistance to many pests and diseases and improved their tolerance to extreme temperatures, salinity and drought - a value that is of growing importance under the changing climate. Given their significance there is a need for the systematic collection and conservation of wild and weedy relatives to improve their representation 
in genebanks. The potential use of some tertiary wild relatives for sorghum improvement definitely exists, although nonconventional breeding methods are needed to overcome crossing barriers. While such techniques are not currently widely accessible to breeders in all sectors, these species may be important gene donors in the future. More genes for desirable characters and higher biological yield are needed for progressive improvement of cultivated sorghum. The availability of such genes depends on identification of geographic regions with a concentration for various characters of agronomic value. The identification of such sites is of paramount importance for designing appropriate sampling strategies for germplasm collection and for selecting appropriate in situ sites to complement ex situ conservation efforts. Choice of sites for in situ conservation may depend on high diversity estimates based on markers or knowledge of adaptive traits linked to certain ecological conditions (Workeye 2002), for example co-evolving hostpathogen systems and adaptation to other stress conditions.

\section{References}

Adugna A, Sweeney PM, Bekele E (2013) Estimation of in situ mating systems in wild sorghum (Sorghum bicolor (L.) Moench) in Ethiopia using SSR-based progeny array data: implications for the spread of crop genes into the wild. J Genet 92: 3-10.

African Agricultural Technology Foundation (2011) Feasibility Study on Striga Control in Sorghum. African Agricultural Technology Foundation, Nairobi, Kenya, p 62.

Aldrich PR, Doebley J (1992) Restriction fragment variation in the nuclear and chloroplast genomes of cultivated and wild Sorghum bicolor. Theor Appl Genet 85: 293-302.

Aldrich PR, Doebley J, Schertz KF, Stec A (1992) Patterns of allozyme variation in cultivated and wild Sorghum bicolor. Theor Appl Genet 85: 451-460.

Alsaadawi IS, Al-Uquaili JK, Al-Rubeaa AJ, Al-Hadithy SM (1986) Allelopathic suppression of weed and nitrification by selected cultivars of Sorghum bicolor L. (Moench). J Chem Ecol 12: 209-219.

Anahosur KH, Laxman M (1991) Estimation of loss in grain yield in sorghum genotypes due to downymildew. Indian Phytopathol 44: 520-522.

Aung T, Thomas H (1976) Transfer of mildew resistance from the wild oat Avena barbata into cultivated oat. Nature 260: 603-604.

AusPGRIS (Australian Plant Genetic Resources Information Services) (2013) Summary Statistics for Species Matching: Sorghum (Online Data base). Available: http:// www. dpi. old. gov. au/extra/asp/AusPGRIS.

Bapat DR, Mote UN (1982) Sources of shoot fly resistance in sorghum. J Maharashtra Agri Univ 7: 238-240.

Ben-Hammouda M, Kremer RJ, Minor HC (1995) Phytotoxicity of extracts from sorghum plant components on wheat seedlings. Crop Sci 35: 1652-1656.

Billot C, Ramu P, Bouchet S, Chantereau J, Deu M et al. (2013) Massive sorghum collection genotyped with SSR markers to enhance use of global genetic resources. PLoS One 8(4): e59714. doi:10.1371/journal.pone.0059714.

Boivin K, Deu M, Rami J-F, Trouche G, Hamon P (1999) Towards a saturated sorghum map using RFLP and AFLP markers. Theor Appl Genet 98: 320-328.

Bonde MR, Freytag RE (1979) Host range of an American isolate of Peronosclerospora sorghii. Plant Dis Rep 63: 650-654.

Bonman JM, Paisooksantivatana Y, Pitipornchai P (1983) Host range of Peronosclerospora sorghi in Thailand. Plant Dis 67: 630-632. 
Borad PK, Mittal VP (1983) Assessment of losses caused by pest complex to sorghum hybrid CSH-5. In: Krishnamurthy Rao BH, Murthy KSRK (eds) Crop Losses due to Insect Pests. Entomological Society of India, Rajendranagar, Hyderabad, AP, India, pp 271-278.

Bowers JE, Abbey C, Anderson S, Chang C, Draye X, Hoppe AH, Jessup R, Lemke C, Lennington J, Li Z, Lin Y-R, Liu S-C, Luo L, Marler BS, Ming R, Mitchell SE, Qiang D, Reischmann K, Schulze SR, Skinner DN, Wang Y-W, Kresovich S, Schertz KF, Paterson AH (2003) A high-density genetic recombination map of sequence tagged sites for sorghum, as a framework for comparative structural and evolutionary genomics of tropical grains and grasses. Genetics 165: 367-386.

Bowers JE, Arias MA, Asher R, Avise JA, Ball RT, Brewer GA, Buss RW, Chen AH, Edwards TM, Estill JC, Exum HE, Goff VH, Herrick KL, Steel CLJ, Karunakaran S, Lafayette GK, Lemke C, Marler BS, Masters SL, McMilliann JM, Nelson LK, Newsome GA, Nwakanma CC, Odeh RN, Phelps CA, Rarick EA, Rogers CJ, Ryan SP, Slaughter KA, Soderlund CA, Tang H, Wing RA, Paterson AH (2005) Comparative physical mapping links conservation of microsynteny to chromosome structure and recombination in grasses. Proc Natl Acad Sci USA 102: 13206-13211.

Bramel-Cox PJ, Cox TS (1988) Use of wild sorghums in sorghum improvement. In: Wilkinson D (ed) Proceedings of the 43rd Annual Corn and Sorghum Industry Research Conference, American Seed Trade Association, Washington DC, USA, pp 13-26.

Browning JA, Frey KJ (1969) Multiline cultivars as a means of disease control. Annu Rev Phytopathol 7: 355-382.

Brush SB (1995) In situ conservation of landraces in centers of crop diversity. Crop Sci 35: 346-354

Casa AM, Mitchell SE, Hamblin MT, Sun H, Bowers JE, Paterson AH, Aquadro CF, Kresovich S (2005) Diversity and selection in sorghum: simultaneous analyses using simple sequence repeats (SSRs). Theor Appl Genet 111: 23-30.

Casa AM, Pressoir G, Brown P, Mitchell SE, Rooney WL, Tuinstra MR, Franks CD, Kresovich $S$ (2008) Community resources and strategies for association mapping in sorghum. Crop Sci 48: 30-40.

CBD (1992) Convention on Biological Diversity. Secretariat of the Convention on Biological Diversity, Montreal, Quebec, Canada.

Celarier RP (1958) Cytotaxonomy of the Andropogoneae. III. Subtribe Sorgheae, genus Sorghum. Cytologia 23: 395-418.

Chang TT (1985) Germplasm enhancement and utilization. Iowa State J Res 54: 399-424.

Chittenden LM, Schertz KF, Lin YR, Wing RA, Paterson AH (1994) A detailed RFLP map of Sorghum bicolor $\mathrm{x}$ S. propinquum, suitable for high density mapping, suggests ancestral duplication of sorghum chromosomes or chromosomal segments. Theor Appl Genet 87: $925-933$.

Clapham A, Rowley-Conwy PA (2007) New Discoveries at Qasr Ibrim, Lower Nubia. In: Cappers R (ed) Fields of Change: Progress in African Archaeobotany. Groningen Archaeological Studies 5. Groningen, The Netherlands, pp 157-164.

Clayton WD (1961) Proposal to Conserve the Generic name Sorghum Moench (Graminae) versus Sorghum Adans (Graminae). Taxon 10: 242.

Craig J, Frederiksen RA (1980) Pathotypes of Peronosclerospora sorghi. Plant Dis 64: 778-779.

Craig J, Odvody GN (1992) Current status of sorghum downy mildew control. In: de Milliano WAJ, Frederiksen RA, Bengston GD (eds) Sorghum and Millet Diseases: Second World Review. ICRISAT, Patancheru, AP, India, pp 213-217.

Cui YX, Xu GW, Magill CW, Schertz KF, Hart GE (1995) RFLP based assay of Sorghum bicolor (L) Moench genetic diversity. Theor Appl Genet 90: 787-796.

D'je Y, Heuertz M, Ater M, Lefebyre C, Vekemans X (2004) In situ estimation of outcrossing rate in sorghum landraces using microsatellite markers. Euphytica 138: 205-212.

Dahlberg JA, Wasylikowa K (1996) Image and statistical analyses of early sorghum remains (8000 B.P.) from the Nabta Playa archaeological site in the Western Desert, southern Egypt. Veg Hist Archaeobot 5: 293-299. 
de Milliano WAJ, Veld MI (1990) Incomplete resistance of the sorghum variety QL-3 (India) against sorghum downy mildew in Zimbabwe. Sorghum Newsl 31: 103.

de Oliviera AC, Richter T, Bennetzen JL (1996) Regional and racial specificities in sorghum germplasm assessed with DNA markers. Genome 39: 579-587.

de Wet JMJ (1978) Systematics and evolution of sorghum sect. Sorghum (Gramineae). Am J Bot 65(4): 477-484.

de Wet JMJ, Huckabay JP (1967) The origin of Sorghum bicolor II. Distribution and Domestication. Evolution 21: 787.

de Wet JMJ, Harlan JR (1971) The origin and domestication of Sorghum bicolor. Econ Bot 25: $128-135$.

Deu M, Hamon P, Chantereau J, Dufour P, D’Hont A, Lanaud C (1995) Mitochondrial DNA diversity in wild and cultivated sorghum. Genome 38: 635-645.

deWet JMJ, Harlan JR, Price EG (1970) Origin of variability in the Spontanea complex of Sorghum bicolor. Am J Bot 57(6): 704-707.

Dillon SL, Lawrence PK, Henry RJ (2001) The use of ribosomal ITS to determine phylogenetic relationships within Sorghum. Plant Syst Evol 230: 97-110.

Dillon SL, Lawrence PK, Henry RJ, Ross L, Price HJ, Johnston JS (2004) Sorghum laxiflorum and $S$. macrospermum, the Australian native species most closely related to the cultivated S. bicolor based on ITS1 and ndhF sequence analysis of 25 Sorghum species. Plant Syst Evoln 249: 233-246.

Dillon SL, Lawrence PK, Henry RJ, Price HJ (2007) Sorghum resolved as a distinct genus based on combined ITS1, ndhF and Adh1 analyses. Plant Syst Evol 268: 29-43.

Dillon SL, Shapter FM, Henry RJ, Cordeiro G, Izquierdo L, Lee LS (2007) Domestication to crop improvement: genetic resources for sorghum and saccharum (Andropogoneae). Ann Bot 100(5): 975-989.

Doggett H (1988) Sorghum, 2nd ed. Longman, Harlow, Essex, UK.

Doggett H, Majisu BN (1968) Disruptive selection in crop improvement. Heredity 23: 1-22.

Downes RW (1971) Relationship between evolutionary adaptation and gas exchange characteristics of diverse Sorghum taxa. Aus J Biol Sci 24: 843-52.

Draye X, Lin Y.R, Qian XY, Bowers JE, Burow GB et al. (2001) Toward integration of comparative genetic, physical, diversity, and cytomolecular maps for grasses and grains, using the sorghum genome as a foundation. Plant Physiol 125: 1325-1341.

Duncan RR, Bramel-Cox PJ, Miller FR (1991) Contributions of introduced sorghum germplasm to hybrids development in the USA. In: Shands HL, Wiesner LE (eds) Use of Plant Introductions in the Cultivar Development, Part 1. Crop Science Society of America, Madison, WI, USA; Special Publication 17: 69-101.

Duvall MR, Doebley JF (1990) Restriction site variation in the chloroplast genome of sorghum (Poaceae). Syst Bot 15(3): 472-480.

Dwivedi SL, Stalker HT, Blair MW, Bertioli DJ, Upadhyaya H, Nielen S, Ortiz R (2008) Enhancing crop gene pools with beneficial traits using wild relatives. Plant Breed Rev 30: 179-230.

Einhellig FA, Souza IF (1992) Phytotoxicity of sorgoleone formed in grain sorghum root exudates. J Chem Ecol 18: 1-11.

Ellstrand NC, Foster F (1983) Impact of population structure on the apparent outcrossing rate of grain sorghum (Sorghum bicolor). Theor Appl Genet 66: 323-327.

FAO (1996) Global Plan of Action for the Conservation and Sustainable Utilization of Plant Genetic Resources for Food and Agriculture. Food and Agriculture Organization of the United Nations, http:/ /www.fao.org/ag/AGP/AGPS/GpaEN/gpatoc.htm.

FAO (2001) International Treaty on Plant Genetic Resources for Food and Agriculture. Food and Agriculture Organization of the United Nations, http://www.fao.org/ag/cgrfa/ itpgr.htm.

FAO (2010) Second Report on the State of the World's Plant Genetic Resources for Food and Agriculture. FAO, Rome, Italy. Available at http://www.fao.org/agriculture/seed/ sow $2 /$ en/. 
FAO (2013) http: / / www.fao.org.

Feltus FA, Hart GE, Schertz KF, Casa, AM, Kresovich S, Abraham S, Klein PE, Brown PJ, Paterson AH (2006) Alignment of genetic maps and QTLs between inter-andintra-specific sorghum populations. Theor Appl Genet 112: 1295-1305.

Fernandes FT, Schaffert RE (1983) The reaction of several sorghum cultivars to a new race of sorghum downy mildew (Peronosclerospora sorghii) in Southern Brazil in 1982-1983. Agron Abstr 27: 63.

Fields of Change. Proceedings of the 4th International Workshop for African Archaeobotany, Groningen, 157-164.

Forney DR, Foy CL (1985) Phytotoxicity of products from rhizospheres of a sorghum Sudangrass hybrid (Sorghum bicolor x Sorghum sudanense). Weed Sci 33: 597-604.

Frankel OH (1973) Survey of crop genetic resources in their centres of diversity. First report. FAO and IBP, Rome, Italy.

Frankel OH, Bennet E (1970) Genetic resources in plants-their exploration and conservation. International Biological Programme Handbook No 11. Blackwell, Oxford, Edinburgh, UK.

Frankel OH, Hawkes JG (1975) Crop Genetic Resources for Today and Tomorrow. International Biological Programme 2. Cambridge University Press, Cambridge, UK.

Frederiksen RA, Duncan RR (1982) Sorghum diseases in North America. In: de Milliano WAJ, Frederiksen RA, Bengston GD (eds) Sorghum and Millet Diseases. Second World Review ICRISAT Patancheru, AP, India, pp 85-88.

Frey KJ (1983) Genes from wild relatives for improving plants. In: Yap TC, Graham KM, Sukhani J (eds) Crop Improvement Research. SABRAO, Kuala Lumpur, Malaysia, pp 1-20.

Fuller DQ (2002) Fifty years of archaeobotanical studies in India. Laying a solid foundation. In: Settar S, Korisettar R (eds). Indian Archaeology in Retrospect. Vol III. Archaeology and Interactive Disciplines. Delhi, India, pp 247-363.

Garber ED (1950) Cytaxonomic Studies in the Genus Sorghum. Univ Calif Publ Bot 23: 283.

Garber ED (1954) Cytotaxonomic studies in the genus Sorghum. III. The polyploid species of the sub-genera Para-Sorghum and Stiposorghum. Bot Gaz 115: 336-342.

GCDT (2007) Strategy for the Global ex situ Conservation of Sorghum. Genetic Diversity Global Crop Diversity Trust, Rome, Italy, p 45.

Geneve RL, Weston LA (1988) Growth reduction of eastern redbud (Cercis canadensis L.) seedlings caused by interaction with a sorghum-Sudangrass hybrid (Sudex). J Environ Hort 6: 6.

Glover JD, Reganold JP, Bell LW, Borevitz J, Brummer EC, Buckler ES, Cox CM, Cox TS, Crews TE, Culman SW, DeHaan LR, Eriksson D, Gill BS, Holland J, Hu F, Hulke BS, Ibrahim AMH, Jackson W, Jones SS, Murray SC, Paterson AH, Ploschuk E, Sacks EJ, Snapp S, Tao D, Van Tassel DL, Wade LJ, Wyse DL, Xu Y (2010) Increased food and ecosystem security via perennial grains. Science 328: 1638-1639.

Goodman RM, Hauptli H, Crossway A, Knauf VC (1987) Gene transfer in crop improvement. Science 236: 48-54.

Gu MH, Ma HT, Liang GH (1984) Karyotype analysis of seven species in the genus Sorghum. J Hered 75: 196-202.

Guarino L, Rao VR, Reid R (1995) Collecting Plant Genetic Diversity: Technical Guidelines. CAB International, Wallingford, Oxford, UK.

Guo JH, Skinner DZ, Liang GH (1996) Phylogenetic relationships of sorghum taxa inferred from mitochondrial DNA restriction fragment analysis. Genome 39(5): 1027-1034.

Harlan JR (1977) Sources of genetic defence. Ann New York Acad Sci 287: 345-356.

Harlan JR (1984) Evaluation of wild relatives of crop plants. In: Holden JHW, Williams JT (eds) Crop Genetic Resources: Conservation and Evaluation. George Allen and Unwin, London, UK, pp 212-222.

Harlan JR (1992) Indigenous African agriculture. In: Cowan CW, Watson PJ (eds) The Origins of Agriculture: An International Perspective. Smithsonian Institution Press, Washington DC, USA, pp 59-70. 
Harlan JR, de Wet JMJ (1971) Towards a rational classification of cultivated plants. Taxon 20(4): 509-517.

Harlan JR, de Wet JMJ (1972) A simplified classification of cultivated sorghum. Crop Sci 12: 172.

Harlan JR, Stemler A (1976) The races of Sorghum in Africa. In: Harlan JR, de Wet JMJ, Stemler A (eds) Origins of African plant domestication. Mouton, Hague, Netherlands, pp 465-478.

Harris KM (1975) Allopatric resistance: Searching for sources of insect resistance for use in agriculture. Environ Entomol 4: 661-69.

Harris KM (1979) Descriptions and host ranges of the sorghum midge, Contarinia sorghicola (Coquillett) (Diptera: Cecidomyiidae), and of eleven new species of Contarinia reared from gramineae and cyperaceae in Australia. Bull of Entomol Res 69: 161-182.

Hartl DL, Clark AG (1989) Principles of Population Genetics. Sinauer Press, Sunderland, Massachussetts, USA.

Hawkes JG (1977) The importance of wild germplasm in plant breeding. Euphytica 26: 615-621.

Hawkes JG, Maxted N, Ford-Lloyd BV (2000). The Ex Situ Conservation of Plant Genetic Resources. Kluwer, Dordrecht, Netherlands.

Heaton EA, Dohleman FG, Long SP (2008) Meeting US biofuel goals with less land: the potential of Miscanthus. Glob Change Biol 14: 2000-2014.

Heslop-Harrison JS (2002) Exploiting novel germplasm. Aus J Agri Res 53: 873-879.

Heywood VH, Dulloo ME (2006) In Situ Conservation of Wild Plant Species—a Critical Global Review of Good Practices. IPGRI Technical Bulletin No 11. IPGRI, Rome, Italy.

Hillis DN (1987) Molecular versus morphological approaches to systematics. Annu Rev Ecol Syst 18: 23-42.

Hodnett GL, Burson BL, Rooney WL, Dillon SL, Price HJ (2005) Pollen-pistil interactions result in reproductive isolation between Sorghum bicolor and divergent Sorghum species. Crop Sci 45: 1403-1409.

House LR (1985) A Guide to Sorghum Breeding. ICRISAT, Patancheru, AP, India.

Hoyt E (1988) Conserving the Wild Relatives of Crops. IBPGR, IUCN, WWF, Rome, Italy.

Hu FY, Tao DY, Sacks E, Fu BY, Xu P, Li J, Yang Y, McNally K, Khush GS, Paterson AH, Li ZK (2003) Convergent evolution of perenniality in rice and sorghum. Proc Natl Acad Sci USA 100: 4050-4054.

Huelgas VC, Lawrence P, Adkins SW, Mufti MU, Godwin ID (1996) Utilization of the Australian native species for sorghum improvement. In: Foale MA, Henzell RG, Knepp JF (eds) Proceedings of 3rd Australian Sorghum Conference. Australian Institute of Agricultural Sciences, Melbourne, Australia, pp 369-375.

ICRISAT (1995) Annual Report, ICRISAT, Patancheru, AP, India.

Jang CS, Kamps TL, Tang H, Bowers JE, Lemke C, Paterson AH (2009) Evolutionary fate of rhizome-specific genes in a non-rhizomatous Sorghum genotype. Heredity 102: 266273.

Jarvis A, Lane A, Hijmans RJ (2008) The effect of climate change on crop wild relatives. Agri Ecosyst Environ 126(1): 13-23.

Jotwani MG, Young WR, Teetes GI (1980) Elements of Integrated Control of Sorghum Pests. FAO Plant Prod. Prot Paper, FAO, Rome, Italy, p 159.

Kamala V (2003) Diversity analysis and Identification of sources resistant to downy mildew, shoot fly and stem borer in wild sorghums. Unpublished PhD Thesis, Osmania University, Hyderabad, AP, India.

Kamala V, Singh SD, Bramel PJ, Manohar Rao D (2002) Sources of resistance to downy mildew in wild and weedy sorghums. Crop Sci 42: 1357-1360.

Kamala V, Sharma HC, Manohar Rao D, Varaprasad KS, Bramel PJ (2009) Wild relatives of sorghum as sources of resistance to sorghum shoot fly, Atherigona soccata. Plant Breeding 128: $137-142$. 
Kamala V, Sharma HC, Manohar Rao D, Varaprasad KS, Bramel PJ, Chandra S (2012) Interactions of spotted stem borer Chilo partellus with wild relatives of sorghum. Plant Breed 131: 511-521.

Kenneth RG (1981) Downy mildews of graminaceae crops. In: Spencer DM (ed) The Downy Mildews. Academic Press, London, UK, pp 367-394.

Khan ZR, Picket JA, van den Berg J, Wadhams LJ, Woodcock CM (2000) Exploiting chemical ecology and species diversity: stem borer and striga control for maize and sorghum in Africa. Pest Manag Sci 56: 957-962.

Khush GS (1977) Disease and insect resistance in rice. Adv Agron 29: 265-341.

Khush GS, Brar DS (1988) Wide hybridization in plant breeding. In: Zakir H (ed) Plant Breeding and Genetic Engineering. SABRAO, Kuala Lumpur, Malayasia, pp 141-188.

Kim C, Zhang D, Auckland SA, Rainville LK, Jakob K, Kronmiller B, Sacks EJ, Deuter M, Paterson AH (2012) SSR-based genetic maps of Miscanthus sinensis and M. sacchariflorus, and their comparison to sorghum. Theor Appl Genet 124: 1325-1338.

Knott DR (1971) The transfer of genes for disease resistance from alien species of wheat by induced translocations. In: Mutation Breeding for Disease Resistance. International Atomic Energy Association, Vienna, Austria, pp 67-77.

Kuhlman LC, Burson BL, Klein PE, Klein RR, Stelly D, Price HJ, Rooney WL (2008) Genetic recombination in Sorghum bicolor-S. macrospermum interspecific hybrids. Genome 51: 749-756.

Laurie DA, Bennett MD (1989) The timing of chromosome elimination in hexaploid wheat $x$ maize crosses. Genome 32: 953-961.

Lazarides M, Hacker JB, Andrew MH (1991) Taxonomy, cytology and ecology of indigenous Australian sorghum (Sorghum bicolor (L.) Moench Andropogoneae, Poaceae). Aus Syst Bot 4(4): 591-635.

Leppik EE (1970) Gene centers of plants as sources of disease resistance. Annu Rev Phytopathol 8: 323-344.

Liang GHL, Casady AJ (1966) Quantitative presentation of the systematic relationships among twenty-one sorghum species. Crop Sci 6: 76-79.

Lin YR, Shertz KF, Paterson AH (1995) Comparative analysis of QTL affecting plant height and maturity across the Poaceae in reference to an interspecific sorghum population. Genetics 141: 391-411.

Lin YR, Zhu LH, Ren SX, Yang JS, Schertz KF, Paterson AH (1999) A Sorghum propinquum BAC library, suitable for cloning genes associated with loss-of-function mutations during crop domestication. Mol Breed 5: 511-520.

Linnaeus C (1753) Species Plantarum. Laurentius Salvius, Stockholm, Sweden.

Mann JA, Kimber CT, Miller FR (1983) The origin and early cultivation of sorghums in Africa. Texas Agric Exp Stn Bull 1454.

Maxted N, Kell SP (2009) Establishment of a Global Network for the In Situ Conservation of Crop Wild Relatives: Status and Needs. FAO Commission on Genetic Resources for Food and Agriculture, Rome, Italy, p 266.

Maxted N, Ford-Lloyd BV, Hawkes JG (eds) (1997a) Plant Genetic Conservation: The In Situ Approach. Chapman \& Hall, London, UK.

Maxted N, Hawkes JG, Guarino L, Sawkins M (1997b) The selection of taxa for plant genetic conservation.Genet Resour Crop Evol 44: 337-348.

Maxted N, Ford-Lloyd BV, Jury S, Kell S, Scholten M (2006) Towards a definition of a crop wild relative. Biodivers Conserv 15: 2673-2685.

Meilleur BA, Hodgkin T (2004) In situ conservation of crop wild relatives. Biodivers Conserv 13: 663-684.

Ming R, Liu SC, Lin YR, da Silva J, Wilson W, Braga D, van Deynze A, Wenslaff TF, Wu KK, Moore PH, Burnquist W, Sorrells ME, Irvine JE, Paterson AH (1998) Detailed alignment of Saccharum and Sorghum chromosomes: comparative organization of closely related diploid and polyploid genomes. Genetics 150: 1663-1682. 
Ming R, Liu S-C, Irvine JE, Paterson AH (2001) Comparative QTL analysis in a complex autopolyploid: candidate genes for determinants of sugar content in sugarcane. Genome Res 11: 2075-2084.

Ming R, Del Monte TA, Hernandez E, Moore PH, Irvine JE, Paterson AH (2002) Comparative analysis of QTLs affecting plant height and flowering among closely-related diploid and polyploidy genomes. Genome 45: 794-803.

Moench (1794) Methodus Plantas Horti Botanici et Agri Marburgensis: a staminum situ describendi/auctore. Marburgi Cattorum: in officina nova libraria academiae. 207.

Morden WC, Doebley J, Schertz KF (1990) Allozyme variation among the spontaneous species of sorghum section Sorghum. Theor Appl Genet 80: 296-304.

Morris GP, Ramu P, Santosh P, Deshpande C, Hash CT, Shah T, Upadhyaya HD, Oscar Riera-Lizarazu, Brown PJ, Acharya CB, Mitchell SE, Harriman J, Glaubitz JC, Buckler ES, Kresovich S (2013) Population genomic and genome-wide association studies of agroclimatic traits in sorghum. Proc Natl Acad Sci USA 110(2): 453-458.

Mote UN (1984) Sorghum species resistant to shoot fly. Indian J Entomol 46: 241-243.

Muraya MM, de Villiers S, Parzies HK, Mutegi E, Sagnard F, Kanyenji BM, Kiambi D, Geiger HH (2011) Genetic structure and diversity of wild sorghum populations (Sorghum spp.) from different eco-geographical regions of Kenya. Theor App Genet 123: 571-583.

Muyekho FN, Barrion AT, Khan ZR (2005) Host range for stemborers and associated natural enemies in different farming systems of Kenya. Afr Crop Sci J 13: 173-183.

Negri V, Tiranti B (2010) Effectiveness of in situ and ex situ conservation of crop diversity. What a Phaseolus vulgaris L. landrace case study can tell us. Genetica 138: 985-998.

Negri V, Maxted N, Veteläinen M (2009) European landrace conservation: an introduction. In: Veteläinen M, Negri V, Maxted N (eds) European Landraces: On-farm Conservation, Management and Use. Bioversity Technical Bulletin 15. Bioversity International, Rome, Italy, pp 1-22.

Nevo E, Zohary D, Brown AHD, Haber M (1979) Genetic diversity and environmental associations of wild barley, Hordeum spontaneum, in Israel. Evolution 33: 815-833.

Ng'uni D, Geleta M, Bryngelsson T (2011) Genetic diversity in sorghum (Sorghum bicolor (L.) Moench) accessions of Zambia as revealed by simple sequence repeats (SSR). Hereditas 148: 52-62.

Nwanze KF, Prasada Rao KE, Soman P (1990) Understanding and manipulating resistance mechanisms in sorghum for control of the shoot fly. In: Proceedings of International Symposium on Molecular and Genetic Approaches to Plant Stress. New Delhi, India, pp T 11.1-T 11.2.

Panasiuk O, Bills DD, Leather GR (1986) Allelopathic influence of Sorghum bicolor on weed during germination and early seedlings. J Chem Ecol 2: 1533-1543.

Pande S, Bock CH, Bandopadhyay R, Narayana YD, Reddy BVS, Lenne JM, Jeger MJ (1997) Downy mildew of sorghum. Information Bulletin no 51. International Crops Research Institute for the Semi-Arid Tropics, Patancheru, AP, India, pp 1-32.

Paterson A, Bowers JE, Bruggmann R, Dubchak I, Grimwood J, Gundlach H, Haberer G, Hellston U, Mitros T, Poliakov A, Schmutz J, Spannag M, Tang H, Wang X, Wicker T, Bharti AK, Chapman J, Feltus FA, Gowik U, Grigoriev IV, Lyons E, Maher CA, Martis M, Narechania A, Otillar RP, Penning BW, Salamov AA, Wang Y, Zhang L, Carpita NC, Freeling M, Gingle AR, Hash CT, Keller B, Klein P, Kresovich S, McCann MC, Ming R, Peterson DG ur-Rahman M, Ware D, Westhoff P, Mayer KFX, Messing J, Rokhsar DS (2009) The Sorghum bicolor genome and the diversification of grasses. Nature 457: 551-556.

Patterson AH, Lin Y, Li Z, Schertz KF, Doebley JF, Pinson SRM, Liu S, Stanzel JW, Irvine JE (1995) Convergent domestication of cereal crops by independent mutations at corresponding genetic loci. Science 69: 1714-1718.

Pawar MN, Frederiksen RA, Mughogho LK, Bonde MR (1985) Survey of the virulence of Peronosclerospora sorghi isolates from India, Ethiopia, Nigeria, Texas (USA), Honduras, Brazil and Argentina. (Abstract). Phytopathology 75: 1374. 
Perumal R, Renganayaki K, Menz MM, Katile S, Dahlberg J, Magill CW, Rooney WL (2007) Genetic diversity among sorghum races and working groups based on AFLPs and SSRs. Crop Sci 47: 1375-1383.

Plucknett DL, Smith NJH, Williams JT, Murthi AN (1987) Genebanks and the World's Food. Princeton University Press, Princeton, USA.

Pratt LH, Liang C, Shah M, Sun F, Wang HM, Reid St.P, Gingle AR, Paterson AH, Wing R, Dean R, Klein R, Nguyen HT, Ma HM, Zhao X, Morishige DT, Mullet JE, Pratt MMC (2005) Sorghum expressed sequence tags identify signature genes for drought, pathogenesis, and skotomorphogenesis from a milestone set of 16,801 unique transcripts. Plant Physiol 139: 869-884.

Prescott-Allen R, Prescott-Allen C (1988) Genes from the Wild: Using Wild Genetic Resources for Food and Raw Materials, 2nd edn. International Institute for Environment and Development/Earthscan Publications, London, UK.

Price HJ, Hodnett, GL, Burson BL, Dillon SL, Rooney WL (2005) A Sorghum bicolor x S. macrospermum hybrid recovered by embryo rescue and culture. Aus J Bot 53: 579582.

Price HJ, Hodnett, GL, Burson BL, Dillon SL, Stelly DM, Rooney WL (2006) Genotype dependent interspecific hybridization of Sorghum bicolor. Crop Sci 46: 2617-2622.

Rebe M, van den Berg J, McGeoch MA (2004) Colonization of cultivated and indigenous graminaceous host plants by Busseola fusca (Fuller) (Lepidoptera: Noctuidae) and Chilo partellus (Swinhoe) (Lepidoptera: Crambidae) under field conditions. Afr Entomol 12: 187-199.

Reddy KVS (1985) Relative susceptibility and resistance of some sorghum lines to stem borers in Western Kenya. Insect Sci Appl 6: 401-404.

Rich PJ, Grenier C, Ejeta G (2004) Striga resistance in the wild relatives of sorghum. Crop Sci 44: 2221-2229.

Rooney WL, Blumenthal J, Bean B, Mullet JE (2007) Designing sorghum as a dedicated bioenergy feedstock. Biofuels Bioprod Biorefining-Biofpr 1: 147-157.

Rosenow DT, Dahlberg JA (2000) Collections, conversion and utilization of sorghum. In: Smith CW, Frederiksen RA (eds) Sorghum: Origin, History, Technology and Production. John Wiley, New York, USA, pp 309-328.

Rowley-Conwy P (1991) Sorghum from Qasr Ibrim, Egyptian Nubia, c.800 BC-AD 1811: a preliminary study. In: Renfrew JM (ed) New light on Early Farming. Edinburgh University Press, Edinburgh, Scotland, UK, pp 192-212.

Rowley-Conwy PA, Deakin WJ, Shaw CH (1997) Ancient DNA from archaeological sorghum (Sorghum bicolor) from Qasr Ibrim, Nubia: implications for domestication and evolution and a review of archaeological evidence. Sahara 9: 23-36.

Schecter Y, de Wet JMJ (1975) Comparative electrophoresis and isozyme analysis of seed proteins from cultivated races of sorghum. Am J Bot 62: 254-261.

Shapter FM, Lee LS, Henry RJ (2008) Endosperm and starch granule morphology in wild cereal relatives.Plant Genet Resour 6: 85-97.

Shapter FM, Dawes MP, Lee LS, Henry RJ (2009a) Aleurone and sub-aleurone morphology in native Australian wild cereal relatives. Aus J Bot 57(8): 688-696.

Shapter FM, Eggler P, Lee LS, Henry RJ (2009b) Variation in granule bound starch synthase I (GBSSI) loci amongst Australian wild cereal relatives (Poaceae). J Cereal Sci 49: 4-11.

Sharma HC (1993) Host plant resistance to insects in sorghum and its role in integrated pest management. Crop Protec 12: 11-34.

Sharma HC, Franzmann BA (2001) Host plant preference and oviposition responses of the sorghum midge, Stenodiplosis sorghicola (Coquillett) (Diptera: Cecidomyiidae) towards wild relatives of sorghum. J Appl Entomol 125: 109-114.

Sharma HC, Reddy BVS, Dhillon MK, Venkateswaran K, Singh BU, Pampapathy G, Folkerstma R, Hash CT, Sharma KK (2005) Host plant resistance to insects in Sorghum: present status and need for future research. Int Sorghum Millets News 146: 36-43. 
Shegro A, Labuschagn, MT, van Biljon A, Shargie NG (2013) Assessment of genetic diversity in sorghum accessions using amplified fragment length polymorphism (AFLP) analysis. Afr J Biotechnol 12(11): 1178-1188.

Shivanna KR, Seetharama N (1997) Wide hybridisation in Sorghum: Studies on crossability barriers in the cross $S$. bicolor $\times$ S. dimidiatum using excised spikelets. Int Sorghum Millets Newsl 38: 96-98.

Smith RD, Dickie JB, Linington SH, Pritchard HW, Probert RJ (2003) Seed Conservation: Turning Science into Practice. Royal Botanic Gardens, Kew, UK.

Snowden JD (1936) The Cultivated Races of Sorghum. Adlard \& Son Ltd., London, UK, p 274.

Snowden JD (1955) The wild fodder sorghums of the section Eu-sorghum. J Lin Soc Bot (Lond) 55: 191-260.

Spangler RE (2003) Taxonomy of Sarga, Sorghum and Vacoparis (Poaceae: 16 Andropogoneae). Aus Syst Bot 16: 279-299.

Spangler RE, Zaitchik B, Russo E, Kellogg E (1999) Andropogoneae: evolution and generic limits in sorghum (Poaceae) using ndhF sequences. Syst Bot 24(2): 267-281.

Stalker HT (1980) Utilization of wild species for crop improvement. Adv Agron 33: 111-146.

Stapf O (1917) Sorghum. In: Prain D (ed) Flora of Tropical Africa, Vol 9, Gramineae (MaydeaePaniceae). L. Reeve., Ashford, Kent, England, pp 104-154.

Stebbins GL (1958) The inviability, weakness, and sterility of interspecific hybrids. Adv Genet 9: 147-215.

Stenhouse JW, Prasada Rao KE, Gopal Reddy VG, Appa Rao S (1997) Sorghum. In: Fucillo D, Sears L, Stapleton P (eds) Biodiversity in Trust. Cambridge University Press, Cambridge, UK, pp 292-308.

Stolton S, Maxted N, Ford-Lloyd B, Kell S, Dudley N (2006) Food Stores: Using Protected Areas To Secure Crop Genetic Diversity. WWF Arguments for Protection Series. Gland Switzerland.

Subudhi PK, Nguyen HT Gilbert ML, Rosenow DT (2002) Sorghum improvement: Past achievements and future prospects. In: Kang (ed) Crop Improvement: Challenges in the Twenty-first Century. Haworth Press, New York, USA, pp 109-160.

Sun Y, Suksayretrup K, Kirkam MB, Liang GH (1991) Pollen tube growth in reciprocal intraspecific pollinations of Sorghum bicolor and S. versicolor. Plant Breed 107(3): 197-202.

Sun Y, Skinner DZ, Liang GH, Hulbert SH (1994) Phylogenetic analysis of sorghum and related taxa using internal transcribed spacers of nuclear ribosomal DNA. Theor Appl Genet 89: 26-32.

Tilman D, Socolow R, Foley JA, Hill J, Larson E, Lynd L, Pacala S, Reilly J, Searchinger T, Somerville C, Williams R (2009) Beneficial biofuels-the food, energy, and environment trilemma. Science 325: 270-271.

van den Berg J (2006) Oviposition preference and larval survival of Chilo partellus (Lepidoptera: Pyralidae) on Napier grass (Pennisetum purpureum) trap crops. Int J Pest Manag 52: $39-44$.

Weston WH (1942) The conidial phase of Sclerospora noblei. Phytopathology 32: 206-213.

Wiersema JH, Dahlberg J (2007) The nomenclature of Sorghum bicolor (L.) Moench (Gramineae). Taxon 56: 941-946.

Williams RJ (1984) Downy mildews of tropical cereals. In: Ingrams DS, Williams PH (eds) Advances in Plant Pathology 2: 1-103.

Workeye F (2002) Morphological and biochemical diversity in chickpea (Cicer arietinum L.) Landraces of Ethiopia. MSc. Thesis, Addis Ababa University, Addis Ababa, Ethiopea.

Wright S (1931) Evolution in Mendelian populations. Genetics 16: 97-159.

Wright S (1978) Evolution and the Genetics of Populations. IV. Variability within and among Natural Populations. University Chicago Press, Chicago, USA.

Zeven AC, Knott DR, Johnson R (1983) Investigation of linkage drag in near isogenic lines of wheat by testing for seedling reaction to races of stem rust, leaf rust, and yellow rust. Euphytica 32: 319-327. 